\title{
WHERE DO YOUNG PEOPLE WORK?
}

\author{
Raffaele Grotti, Helen Russell, and Jacqueline 0'Reilly
}

\subsection{INTRODUCTION}

A considerable body of comparative research on youth labor markets has focused on differences in school-to-work (STW) transitions and their impact on youth employment. Much of this research has examined institutional factors, comparing the performance of different vocational education and training (VET) systems, the effectiveness of active labor market policies, wage-setting arrangements, or the need for young people to have greater employability skills. However, surprisingly little attention has been given to employers' behavior or to identifying which sectors of the economy are more open to employing young people and how these have changed over time. This chapter seeks to address this gap by examining where young people (aged 16-24 years) have been employedprior to and since the Great Recession of 2008-2009.

\subsection{COMPARING YOUTH TRANSITIONS ACROSS COUNTRIES AND SECTORS}

\subsubsection{Country Comparisons}

Comparative employment research has drawn on a range of different analytical frameworks that can be used to understand youth employment. These range from polarized "ideal types," such as the Varieties of Capitalism (Hall and Soskice 2001), to more complex typologies encompassing a broader range of variables (O'Reilly 2006). These typologies focus not only on VET systems, wage setting, 


\section{4}

trade unions, and employers' organizations but also on labor market policies and labor market characteristics, as well as cognitive conceptions of what kind of problem youth unemployment represents for policymakers (Russell and O'Connell 2001; Wallace and Bendit 2009; Buchmann and Kriesi 2011).

Using a multidimensional approach, Pohl and Walther (2007) classify countries into five types of "youth transition regimes": universalistic (Denmark, Finland, and Sweden); employment-centered, primarily based on dual training (Austria and Germany), but also including school-based (France) or mixed (Netherlands) training; liberal (Ireland and the United Kingdom); subprotective (Cyprus, Italy, Greece, Portugal, and Spain); and post-socialist, which includes a mixed liberal and employment-centered approach (e.g., Baltic states, Bulgaria, Romania, Slovenia, and Slovakia). This comparative framework provides a parsimonious heuristic device for making systematic comparisons of trends in youth employment between countries (for a fuller discussion of this typology, see Hadjivassiliou et al., this volume).

\subsubsection{Sectorial Comparisons}

Here, we are interested in differences in youth employment not only between countries and regime types but also between sectors within countries-a topic that has received surprisingly little attention (Marsden and Ryan 1986). Crossnational research has tended to focus either on macroeconomic factors and the effects of labor market policies or on supply-side comparisons of youth "employability." More qualitative sectorial studies of employer engagement have either examined differences within one country (Simms, Gamwell, and Hopkins 2017) or evaluated the impact of labor market policies in particular sectors, again often within one country (Lewis and Ryan 2008). Overall, there has been a remarkably limited examination of the role of employers and of sectorial trends in understanding changes in youth employment from a cross-national perspective.

An early comparative study from Marsden and Ryan (1986) asked, "Where do young workers work?" These authors established that youth employment was not evenly distributed across sectors; in fact, services and some areas of manufacturing were more open to youth than other sectors (Marsden and Ryan $1986,85)$. Within countries, considerable variation between "youth-friendly" sectors emerged, but this distribution was very similar across all six countries the authors examined. At the time this research was carried out (1972), and focusing only on male youth, the most popular sectors were footwear, clothing, wood products, and textiles-all largely manufacturing jobs.

More recent studies by Blanchflower and Freeman (2000), using Organization for Economic Co-operation and Development (OECD) data from 1994, have revealed the persistent uneven distribution of youth employment across sectors. Blanchflower and Freeman distinguished between "youth-intensive" industries, in which there is a higher ratio of younger to older workers, ${ }^{1}$ and they found 
that young people (aged 16-24 years) were more likely to be employed in hotels and restaurants, retail, and repair than in utilities, education, or public administration. Two sectors (hotel and restaurants, and retail) accounted for 39\% of all young workers in Germany and France in 1994. Gender differences were also identifiable, with young men being disproportionately employed in construction and young women disproportionately in the health sector. Like Marsden and Ryan before them, these authors found that "the uniformity of these patterns across countries is striking and suggests that, differences in school to work transition patterns notwithstanding, what happens to the youth labor market depends critically on developments in a limited set of sectors in all countries" (p. 47).

\subsubsection{Gender Segregation}

Greater attention has been given to sectorial comparison of the changing composition of employment in studies on gender segregation and the Great Recession. Bettio and Verashchagina (2014) found that the concentration of women in the public sector and in services shielded them from the worst job losses. Rubery and Rafferty (2013) also emphasize the role of gender segregation in their analysis of the crisis in the United Kingdom; they argue that recession and restructuring may induce changes in segregation through substitution that will result in higher unemployment rates for women. Kelly et al. (2014) show that gender segregation in Ireland fully accounts for the observed gender differential in unemployment rates during the recent recession: The hyper-concentration of young men in construction was a significant factor in the disproportionate rise in male youth unemployment.

This body of research indicates that not only is youth employment concentrated in particular sectors but also this varies significantly by gender. As a result, we might expect the consequences for youth employment opportunities to be sensitive to how these sectors were affected by the Great Recession.

\subsubsection{Comparing the Quality of Employment}

In addition to the quantity of jobs created or destroyed, there has also been a long-running interest in the quality of youth employment. Marsden and Ryan (1986) were also interested in understanding the quality of employment that young people can access and how pay rates affect their employment opportunities. They argued that young people have greater difficulty entering jobs where adult wages are high and jobs are well protected. Employers are more likely to view young people as less productive and relatively expensive compared to older workers, if they are expected to treat them on similar terms of employment. Young workers are likely to find it easier to enter low-wage, low-skilled jobs, for which there is less competition from older workers. In sectors where employers can pay apprentices lower rates of pay, this has encouraged higher rates of youth employment. The quality of these jobs could be enhanced where 
there was a good apprenticeship system in place, as evidenced by Germany, which overall has a much higher proportion of skilled young workers compared to other countries.

More recent analysis from Blanchflower and Freeman $(2000,49)$ expected the youth share of employment for 20- to 24-year-olds to increase between 1985 and 1994. Demographic trends with falling numbers of youth, increased educational participation, and the growth of a youth-friendly service sector should have led to an increase in the youth share of employment. Instead, this share fell, and the quality of youth employment and earnings deteriorated in nearly all OECD countries. Blanchflower and Freeman attribute this to the worsening conditions of low-paid and less skilled jobs.

\subsubsection{Declining Demand for Youth Labor}

In addition to the previously mentioned deterioration, Blanchflower and Freeman (2000) argue that there has been a "massively declining labor demand for young workers" (p. 54). A similar finding has been provided in a more recent analysis from Boeri and Jimeno $(2015,4)$. The latter authors attribute the explosion of European youth joblessness since the Great Recession to a massive elimination of jobs held by young people and to a hiring freeze by employers. Indeed, employers' first response to decreases in demand is to stop recruiting and to not renew temporary contracts when they expire. Boeri and Jimeno argue that the destruction of jobs for young people came about with the "dissolution of temporary contracts, while at the same time employment rates among older workers were increasing" (p. 4). As Boeri and Jimeno acknowledge, this is a distinct feature of the Great Recession. In previous economic downturns, older workers were incentivized to leave the labor market via early retirement plans. In the recent period, fiscal consolidation has led to increasing retirement ages to the detriment of employment among young people. Boeri and Jimeno cite this as one example of a more general thesis: Reforms that are effective in normal times may not be desirable during major recessions. However, older workers are not a direct substitute for younger workers because they have different skills and experience that employers value (Eichhorst et al. 2014).

Countries also show different capacities for integrating young people. Despite country similarities in the distribution of youth-friendly jobs across sectors, there was significant variation between countries in the proportions of employed youth. The Marsden and Ryan (1986) study found that some countries, such as Italy, had very low shares of youth employment, whereas these rates were much higher in the United Kingdom. Country differences clearly have had a long-term impact on how many young people are integrated into paid work, where that work is located, and the status it is accorded. This variation is likely to derive from both long-term processes (related to change in the economic structure and labor market institutional characteristics) and short-term cyclical effects, which elicit 
different national policy responses (Blanchflower and Freeman 2000; O'Higgins 2012; Boeri and Jimeno 2015).

Some accounts of the declines in youth employment attribute them to the impact of the economic crisis on particular sectors. Okun's law predicts that the depth of the recession, measured as a decline in gross domestic product (GDP), has a direct correlation with the rise in unemployment. However, O'Higgins (2012) suggests that Okun's law is not well supported in the European case. For example, Ireland experienced a 12\% drop in GDP and a disproportionally large fall of $53 \%$ in youth employment; the explanation, he argues, while including an account of other countries, is largely related to a fall in aggregate labor demand (O'Higgins 2012, 21). Boeri and Jimeno (2015) draw a similar conclusion to that of O'Higgins (2012). Although they argue that Okun's law can account for approximately $50 \%$ of the change in youth jobs in Europe, it does not explain the "unbearable divergence of unemployment in Europe." This divergence, they believe, is the product of both shocks of varying intensity and different labor market responses. Policy options include increasing wage flexibility or employment flexibility, where this can mean either cuts in the number of hours worked or cuts in the number of people employed. Whether youth unemployment is a long-term structural characteristic related to labor market institutions or the result of short-term cyclical effects is contested; Boeri and Jimeno $(2015,4)$ suggest that even long-term structural characteristics fluctuate too much over time.

\subsubsection{Research Questions}

Evidence from this literature suggests three possible lines of investigation to understand how sectorial differences affected youth employment rates during the Great Recession. First, changes to the overall size of youth-friendly sectors can explain why the youth job market worsened, or in a few cases improved. We can hypothesize that part of the explanation for the growth in youth unemployment is related to how the size of these sectors changed since 2007. Did young people lose their jobs because the sector shrunk as a result of economic shock and the recession? This would be a reasonable expectation in countries in which youth were disproportionately employed in the construction sector and in which there had been a housing bubble leading up to 2007 (Boeri and Jimeno 2015). Or, second, did the fall in youth employment come about because employers' propensity to employ young workers declined? This would be evidenced by a decline in the youth:older worker ratio. Third, was the growth of youth unemployment only a consequence of the destruction of temporary jobs; that is, was it easier to get rid of young people, especially in dualist labor markets? Or, have youth job opportunities continued to deteriorate with the growth of lower quality employment, in the way identified by Blanchflower and Freeman (2000)? 


\subsection{RESEARCH DESIGN, DATA, MEASURES, AND METHODS}

To answer the previous questions, we draw on European Union Labour Force Survey (EU-LFS) data, examining where young people (aged 16-24 years) have been employed and how this changed between 2007 and 2014. First, we examine the descriptive statistics on youth unemployment and labor force participation trends for the five country groups over three decades (from 1983, where possible, to 2014). The 23 countries considered have been chosen in order to maximize the time span over which we can assess the trends. At the same time, so as to have consistent aggregate measures, the countries chosen have data for the entire period. ${ }^{2}$ We present aggregate trends for two measures: the youth unemployment rate and the youth labor force participation rate.

The youth unemployment rate represents the share of unemployed youth among the active-that is, employed or unemployed-youth labor force population. Students and other inactive youth are not included in this estimate. In contrast, the labor force participation rate records the share of economically active youth over the total youth population, including those who are inactive. We decided to complement the measure of unemployment rate with the measure of participation rate in order to provide a more comprehensive picture of the nonemployment phenomenon among youth and of the heterogeneity among country groups in the forces that have driven unemployment trends. Indeed, focusing only on the unemployment rate risks missing important aspects of the phenomenon (O'Reilly et al. 2015). This is because variations in the unemployment rate may be the result both of flows between unemployment and employment and of flows from unemployment or employment to inactivity, and vice versa (O’Higgins 2012; Berloffa et al., this volume; Flek, Hála, and Mysíková, this volume); for a discussion of measures of youth not in employment, education, or training (NEETs), see Mascherini (this volume).

Second, we select 11 countries that represent the five country groups to provide a more in-depth analysis identifying where young people have been employed and how this has changed over three time points: before (2007), during (2010), and after (2014) the Great Recession. The countries selected are Denmark and Sweden for the universalistic group; France, Germany, and the Netherlands representing the employment-centered countries; Ireland and the United Kingdom for the liberal countries; Italy and Spain for the subprotective countries; and Hungary and Poland representing the post-socialist countries. By including pairs of countries for each regime type, we can also identify differences within these categories.

Third, we use a shift-share analysis to address our research question as to whether young people lost their jobs because a sector reduced in size or because it became less youth friendly, suggesting a reduction in employers' propensity to employ young people. This allows us to disaggregate changes in employment by economic activity. It also enables us to answer our third research question 
regarding the deteriorating quality of jobs for youth by drawing on other relevant characteristics relating to employment status (full-time/part-time and permanent/temporary employment) and demography (age and gender). This method is particularly suitable for our purposes. It allows us to decompose aggregate changes in total employment resulting from different driving forces: the structural change in the overall size of sectors (growth effect), the change in the proportion of youth workers in each sector (share effect), and the interaction between these two forces (interaction effect).

More formally, where $Y_{t}$ is the share of youth over total employment in year $t$, we can write

$$
Y_{t}=\sum_{i} T_{i, t} p_{i, t}
$$

where $T_{i, t}$ represents total employment in sector $i$ in year $t$, and $p_{i, t}$ is the share of youth employment over total employment in sector $i$ in year $t$. Then, based on these two quantities, we can decompose the changes in the share of youth employment as follows:

$$
\begin{array}{rlrl}
\Delta Y_{t}= & Y_{t}-Y_{t-1}= & \\
= & \sum_{i}\left(T_{i, t}-T_{i, t-1}\right) p_{i, t-1} & & \text { Growth effect } \\
& +\sum_{i}\left(p_{i, t}-p_{i, t-1}\right) T_{i, t-1} & & \text { Share effect } \\
& +\sum_{i}\left(p_{i, t}-p_{i, t-1}\right)\left(T_{i, t}-T_{i, t-1}\right) & & \text { Interaction effect }
\end{array}
$$

This equation can be further decomposed to disaggregate changes in youth employment by subgroups-for example, distinguishing between males and females or distinguishing youth according to their employment status (i.e., full-time, part-time, or temporary employment). In these cases, the aggregate changes, as well as the contribution of the different effects, do not change but are simply further disaggregated by additional characteristics.

Throughout the chapter, we define employment in accordance with the International Labour Organization definition. Under this definition, anyone working at least 1 hour during the reference week is considered employed, which includes, for example, students working part-time. This has possible implications for the comparative dimension of the study because in some countries, such as the Nordic states, students are more likely to work than in others, leading to a higher estimation of youth employment.

The self-employed are included with the employed, except when we examine temporary/permanent contracts, because this characteristic applies only to employees. Less than $5 \%$ of employed youth are self-employed, with the 


\section{0}

exception of Poland, Spain, and especially Italy (see Ortlieb, Sheehan, and Masso, this volume). As we will show, the results that exclude the self-employed are in line with the results for total employment.

Finally, in the decomposition analyses, the categorization of the sectors is based on the NACE statistical classification of economic activities in the EU (Eurostat 2008). ${ }^{3}$ Shift-share analysis furnishes descriptive understandings of the shifting trends over time and allows us to investigate whether changes in youth employment are driven by structural shifts in the growth or shrinkage of particular economic sectors or whether they are attributable to changes in employers' propensity to employ young people. ${ }^{4}$

\subsection{TRENDS IN YOUTH UNEMPLOYMENT AND ACTIVITY RATES}

The recession of 2008-2009 marked the end of a period of fairly continuous growth in youth employment during the early years of the millennium. Since 2008 , youth unemployment has soared dramatically in subprotective, liberal, and post-socialist countries (Figure 2.1). The subprotective countries have had some of the highest levels of youth unemployment, even since the mid-1980s, while
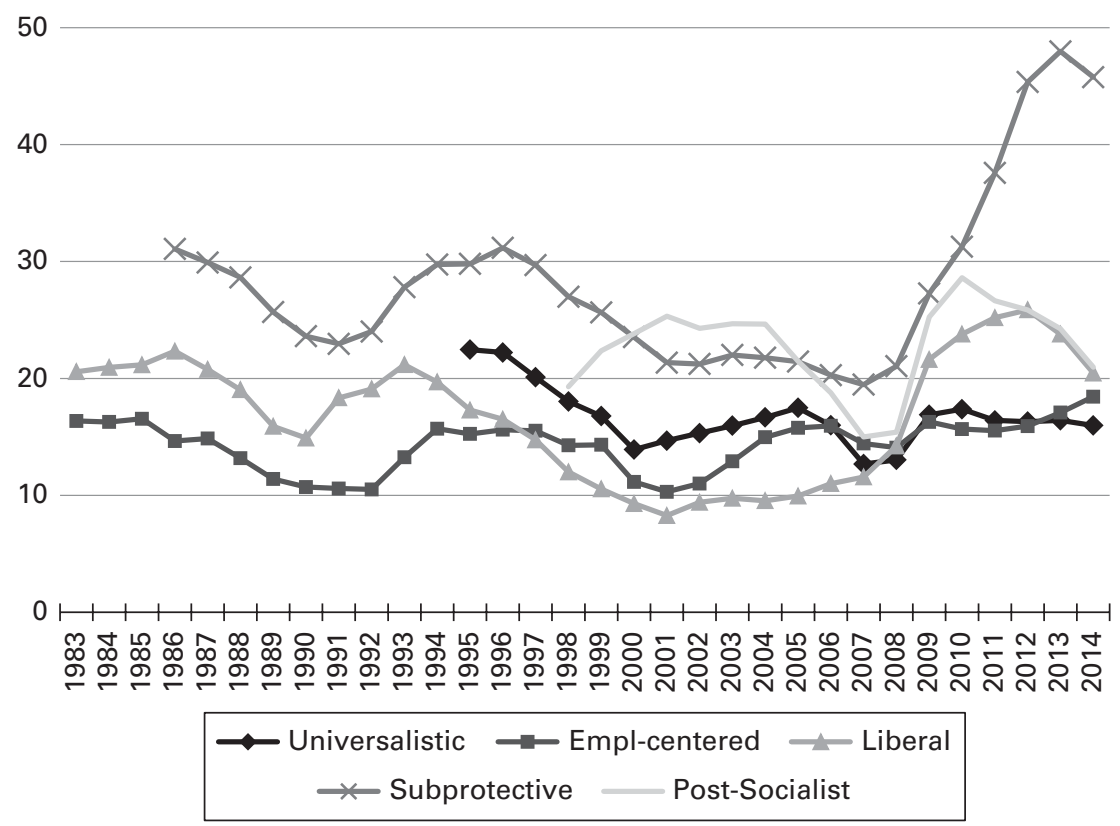

Figure 2.1 Trends in youth (aged 16-24 years) unemployment rate in 11 EU countries, grouped by youth transition regime: 1983-2014 (\%).

Source: EU-LFS; authors' analysis. 
youth unemployment rates were also high in liberal countries during the 1980s. Toward the end of that decade, youth unemployment began to fall in both regions, but then it increased again coming into the mid-1990s. Until the Great Recession in 2008-2009, youth unemployment had been falling across most regions. The exception to this trend was the post-socialist countries, which experienced very high levels of youth unemployment in the 1990s. However, by the mid-2000s, this was also beginning to change, mainly driven by Poland and Slovakia, so that by 2007 the overall levels for this group of countries were converging with the levels in other European countries. The fluctuating trend in unemployment characterizing the employment-centered regime did not result in substantial variation between the beginning of our observational window and the pre-recession period, although notable variations were present during that time. The universalistic countries, which we observe from the mid-1990s, experienced a decline in youth unemployment up until the end of the century, which was mainly driven by reductions in youth unemployment in Sweden and, above all, in Finland. Overall, prior to the Great Recession, trends in the rate of youth unemployment appeared to be converging over time between country groups. Indeed, at the outset of the recession, youth unemployment ranged from $12 \%$ to $15 \%$ for all groups of countries apart from the subprotective, which registered a value of $19 \%$.

With the onset of the recession, more variation between country groups can be observed. At one extreme, there are the universalistic and employment-centered countries, where youth unemployment grew slightly at the very beginning of the recession and then stabilized. Germany had experienced rising levels of youth unemployment up until 2005 (Kohlrausch 2012), but, unlike any other country, youth unemployment fell there during the recession. At the other extreme, in the subprotective countries, where youth unemployment was already very highdriven especially by Spain and Greece-the rate more than doubled to staggeringly high levels with the onset of the recession in 2008. In the middle are the liberal and post-socialist countries, which witnessed a notable increase in youth unemployment in the first years of the recession and a subsequent decrease. However, these declines have not counterbalanced the steep growth in the immediate postcrisis period. In these two country groups, the countries driving the upward trends were Ireland, Latvia, and Lithuania. By 2014, we observed a convergence between country groups, with the youth unemployment rate ranging from $16 \%$ to $21 \%$ everywhere, apart from the subprotective cluster, which has a youth unemployment rate of $46 \%$.

Looking at unemployment rates only, however, may hide important dynamics of the phenomenon. For example, the unemployment rate does not capture the outflow of individuals from the pool of the active population, which is more widespread among youth than among prime-age workers (see Flek et al., this volume). Greater difficulties in making the transition from school to work can lead young people to stay longer in education. Several countries in fact witnessed 


\section{2}

increases in enrollments in higher education during the Great Recession (OECD 2013). The recession may also have led to "discouragement" among young people, who gave up on the labor market when job search failed. The problem of NEETs highlights this latter issue (see Mascherini, this volume). For these reasons, the picture presented previously should be interpreted in light of the evolution of youth labor market participation (Figure 2.2). Unemployment dynamics can thus be seen as the result of both demand- and supply-side factors.

Here, we see that the universalistic countries have the highest levels of youth labor market participation and that this has been fairly constant over the observed period. Overall, for the other countries, there is a fall in youth labor market participation rates from the 1980s until the late 1990s, arguably because of the increasing number of young people staying on in education. From the late 1990s onward, youth participation stabilized up until the recession in the liberal and employment-centered countries. In the post-socialist countries, after a steep decline, youth participation stabilized around the mid-2000s, while the subprotective countries experienced an uninterrupted decline.

With the onset of the Great Recession, young people started to exit again from the labor market in four country groups out of five. The post-socialist group is

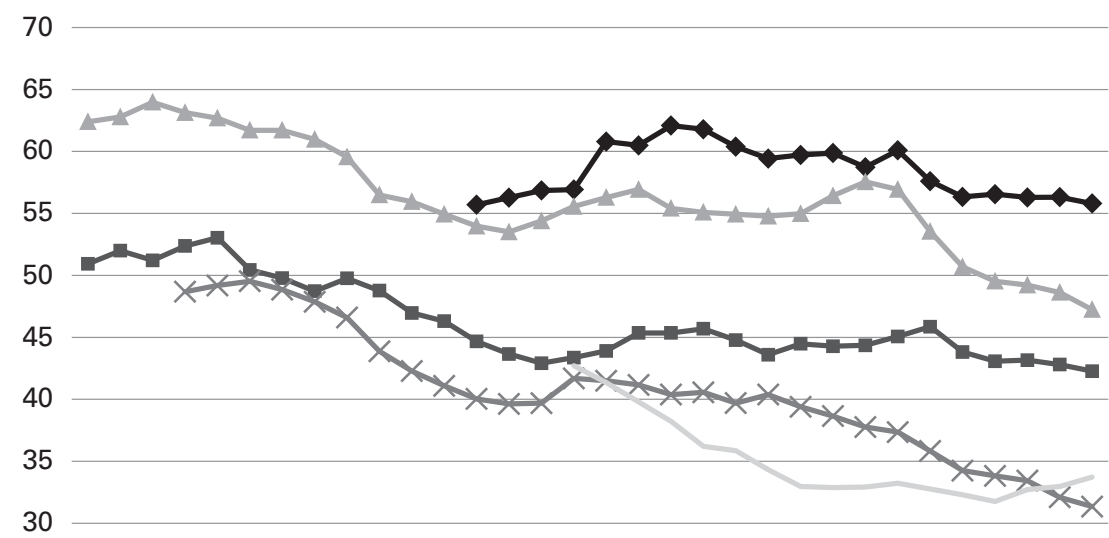

25

20

ఋ

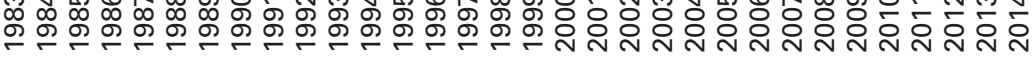

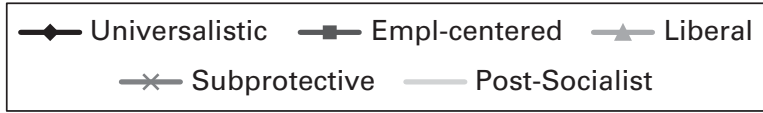

Figure 2.2 Trends in youth (aged 16-24 years) labor force participation rate in 11 EU countries, grouped by youth transition regime: 1983-2014 (\%).

Source: EU-LFS; authors' analysis. 
the exception. A particularly marked decline is observed for the liberal and the subprotective groups.

The combined trends in youth unemployment and labor market participation provide a more complete picture of the consequences of recession for youth in terms of jobs lost. This is particularly true for the young people in the liberal group and especially in the subprotective group, who experienced the highest decline in labor market participation and the largest increase in unemployment. The phenomenon of youth exclusion from the labor market is far more substantial if we consider both indicators jointly, as discussed by Blanchflower and Freeman (2000).

The heaviest consequences of the Great Recession have been paid by Mediterranean youth, where almost one in two young people were unemployed in the last phase of the recession. If we do not limit our focus to the active youth population but expand our attention toward the labor market participation of youth, the scenario is even more stark. Indeed, the trends for labor force participation show that a growing share of youth is giving up or postponing employment and moving into inactivity. The consequences of this latter trend depend on the extent to which young people are remaining longer in education or are stuck in other forms of "inactivity" (see Mascherini, this volume).

\subsection{CROSS-NATIONAL VARIATION IN THE YOUTH SHARE OF EMPLOYMENT}

As Marsden and Ryan (1986) noted, countries vary significantly in terms of the proportion of all employment occupied by young people; this characteristic persists, as evidenced in Table 2.1, which reports the share of youth (aged 1624 years) employment among total (aged 16-64 years) employment. Overall, the universalistic and liberal countries together with the Netherlands and Germany had the highest youth shares of employment. In 2014, this ranged from nearly $15 \%$ in Denmark and the Netherlands to approximately 10\% in Finland and Germany. Seven years previously, Ireland would have topped the list, along with a number of post-socialist countries, where young people accounted for a sizable percentage of all those at work. However, by 2014, many of these countries had seen a decimation of young people in employment: Ireland experienced a fall in the youth share from $16 \%$ to just under $8 \%$ during this period; the youth share of employment was also halved in Spain and Portugal, with a drop from just under $10 \%$ of all employment in 2007 to less than 5\% in 2014.

The youth share of employment fell by between 1 and 2 percentage points (pp) in most of the other countries considered between 2007 and 2014. The only exceptions are the universalistic countries, where youth employment decreased only slightly or even increased, as was the case in Sweden. The countries with the 


\section{COMPARING PROBLEMATIC YOUTH TRANSITIONS TO WORK}

Table 2.1 Youth employment (ages 16-24 years) as a share of total employment (ages 16-64 years) in 23 EU countries: 2007, 2010, and 2014 (\%)

\begin{tabular}{|c|c|c|c|c|}
\hline Transition regime & Country & 2007 & 2010 & 2014 \\
\hline \multirow[t]{4}{*}{ Universalistic } & Denmark & 14.4 & 14.7 & 14.5 \\
\hline & Norway & 13.2 & 13.1 & 12.8 \\
\hline & Sweden & 9.9 & 11.0 & 11.2 \\
\hline & Finland & 11.5 & 10.2 & 10.8 \\
\hline \multirow[t]{2}{*}{ Liberal } & United Kingdom & 13.9 & 13.0 & 12.8 \\
\hline & Ireland & 16.1 & 10.4 & 7.9 \\
\hline \multirow[t]{5}{*}{ Employment-centered } & Netherlands & 15.5 & 15.1 & 14.8 \\
\hline & Germany & 11.7 & 11.2 & 10.2 \\
\hline & France & 9.3 & 8.9 & 8.0 \\
\hline & Belgium & 8.2 & 7.5 & 6.9 \\
\hline & Luxembourg & 6.4 & 6.3 & 5.4 \\
\hline \multirow[t]{8}{*}{ Post-socialist } & Lithuania & 8.3 & 6.9 & 8.3 \\
\hline & Latvia & 12.7 & 9.1 & 8.0 \\
\hline & Estonia & 10.6 & 8.2 & 8.0 \\
\hline & Poland & 9.7 & 8.7 & 7.1 \\
\hline & Hungary & 6.7 & 5.9 & 6.4 \\
\hline & Slovakia & 9.9 & 7.1 & 6.3 \\
\hline & Czech Republic & 7.9 & 6.8 & 6.2 \\
\hline & Romania & 8.8 & 7.3 & 6.1 \\
\hline \multirow[t]{4}{*}{ Subprotective } & Portugal & 9.1 & 7.2 & 5.9 \\
\hline & Spain & 9.9 & 6.5 & 4.5 \\
\hline & Italy & 6.5 & 5.5 & 4.3 \\
\hline & Greece & 6.9 & 5.6 & 4.2 \\
\hline
\end{tabular}

Source: EU-LFS; authors' analysis.

lowest proportion of working youth in 2007 were Luxembourg, Italy, Hungary, and Greece, where youth younger than 25 years accounted for approximately $6 \%$ of all workers. By 2014, these shares had fallen to approximately $4 \%$ of all employment in Italy and Greece.

However, an employer "hiring freeze" (interpreted as employers' lower propensity to employ young people aged 16-24 years as a share of the 16- to 64-yearold population) is not the only factor that might influence the declining youth share of employment. Increased enrollment in school and a greater number of NEETs may also have contributed to this trend. Demographic trends might likewise have played a role. Declining fertility or rising emigration could lead to 
a shrinking youth population and a consequent reduction in the youth labor supply. ${ }^{5}$

\subsection{IN WHICH SECTORS ARE YOUNG PEOPLE EMPLOYED?}

Looking in more detail at sectorial patterns, we focus separately by gender on developments in 11 countries (with 2 or 3 countries representing each country group). ${ }^{6}$ Table 2.2 reports the three main sectors in which female and male youth were employed in the periods pre (2007) and post (2014) the Great Recession (Tables A2.2a and A2.2b in the Appendix report the complete figures for females and males, respectively).

A common feature of employment for young women across all 11 countries examined is the importance of the wholesale and retail sector (labeled D in Table 2.2). This sector accounts for more than one in three jobs for young women in Denmark and the Netherlands and for one in four jobs in Ireland, the United Kingdom, Spain, Italy, and Poland (2014 figures). The lowest this figure falls is $19 \%$ in Germany. There are, however, differences in the importance of other sectors as employers of young women across countries and country groups. The health sector $(\mathrm{K})$ accounts for a significantly higher proportion of female youth employment in the universalistic countries (Denmark and Sweden) and the employment-centered countries (Germany, France, and the Netherlands), whereas in the liberal and subprotective countries, the accommodation and food sector (F) is the second highest employer of young women, accounting for between $14 \%$ and $22 \%$ of their total employment. The two post-socialist countries, and to a lesser extent Germany and Italy, have a distinctly high level of manufacturing sector (B) employment. However, in all four of these countries, manufacturing employment declined between 2007 and 2014.

The wholesale and retail sector also accounts for a significant proportion of employment for young men in all 11 countries, suggesting that there are lower barriers to entry in this sector. In 2014, the proportion of young men employed in wholesale/retail varied from $33 \%$ in the Netherlands to $14 \%$ in Hungary. Country variation appears to be somewhat greater for young men than for young women; in particular, there is wide divergence in the importance of manufacturing. Prerecession, in 2007, manufacturing accounted for approximately one-third of male youth employment in Germany, Hungary, and Poland but only for 13\%15\% in Denmark, the Netherlands, Ireland, and the United Kingdom. Over time, the proportion of young men employed in the manufacturing sector decreased in all countries except Ireland, Hungary, and Poland, but the fall was particularly sharp in Denmark, Sweden, and Spain.

Because of the housing bubble, a distinctively high percentage of young men were employed in construction (C) in Spain and Ireland in $2007-34 \%$ and $27 \%$, 
Table 2.2 The three main sectors in which youth (aged 16-24 years) are employed in 11 EU countries by gender: 2007 and 2014 (employment shares)

\begin{tabular}{|c|c|c|c|c|c|c|c|}
\hline \multirow[b]{2}{*}{ Country } & \multirow[b]{2}{*}{ Period } & \multicolumn{3}{|c|}{ Female } & \multicolumn{3}{|c|}{ Male } \\
\hline & & 1st & 2nd & $3 r d$ & 1st & 2nd & 3 rd \\
\hline \multirow[t]{2}{*}{ Denmark } & 2007 & $\mathrm{D}(34.0)$ & K (17.7) & $F(11.4)$ & D (29.5) & B (15.2) & C (14.4) \\
\hline & 2014 & D (34.4) & K (18.1) & $F(14.4)$ & $\mathrm{D}(30.3)$ & $F(10.5)$ & $C(10.3)$ \\
\hline \multirow[t]{2}{*}{ Sweden } & 2007 & $\mathrm{D}(22.8)$ & K (20.8) & $F(14.0)$ & D (18.8) & $\mathrm{H}(14.2)$ & C (13.9) \\
\hline & 2014 & $\mathrm{D}(21.1)$ & $\mathrm{K}(20.2)$ & F (14.1) & D (17.8) & $H(13.9)$ & B (11.7) \\
\hline \multirow[t]{2}{*}{ Ireland } & 2007 & D (30.6) & $F(16.2)$ & K (10.7) & $C(33.5)$ & D (19.9) & B (13.5) \\
\hline & 2014 & D (29.1) & $F(22.2)$ & K (14.2) & D (25.1) & $F(19.2)$ & B (13.8) \\
\hline \multirow[t]{2}{*}{ United Kingdom } & 2007 & $\mathrm{D}(28.0)$ & $F(13.8)$ & K (13.1) & $\mathrm{D}(25.5)$ & C (16.3) & B (14.3) \\
\hline & 2014 & D (24.6) & $F(16.9)$ & K (16.4) & $\mathrm{D}(22.2)$ & $F(13.3)$ & B (13.3) \\
\hline \multirow[t]{2}{*}{ Germany } & 2007 & D (19.4) & K (19.3) & B (15.0) & B (34.2) & D (14.2) & C (13.1) \\
\hline & 2014 & K (22.5) & D (18.6) & B (12.7) & B (28.9) & D (17.6) & $C(12.8)$ \\
\hline \multirow[t]{2}{*}{ France } & 2007 & D (22.1) & K (17.4) & H (11.0) & $C(20.8)$ & B (19.9) & D (18.3) \\
\hline & 2014 & $\mathrm{D}(23.7)$ & K (19.9) & $\mathrm{H}(10.2)$ & D (18.8) & B (16.5) & $C(16.3)$ \\
\hline \multirow[t]{2}{*}{ Netherlands } & 2007 & D (31.3) & K (18.6) & $F(13.8)$ & D (27.8) & B (12.9) & $\mathrm{H}(11.8)$ \\
\hline & 2014 & D (37.1) & K (19.4) & $F(12.6)$ & D (33.4) & $F(15.2)$ & H (11.8) \\
\hline \multirow[t]{2}{*}{ Spain } & 2007 & D (30.9) & $F(13.8)$ & B (10.6) & $C(27.0)$ & B (20.9) & D (15.9) \\
\hline & 2014 & D (27.4) & $F(20.8)$ & K (11.8) & D (20.9) & $F(15.8)$ & B (14.6) \\
\hline \multirow[t]{2}{*}{ Italy } & 2007 & $\mathrm{D}(23.5)$ & B (17.1) & $F(14.5)$ & B (29.0) & C (19.3) & D (17.5) \\
\hline & 2014 & D (24.7) & $F(21.6)$ & L (14.6) & B (27.3) & D (18.6) & $F(15.6)$ \\
\hline \multirow[t]{2}{*}{ Hungary } & 2007 & $\mathrm{D}(25.2)$ & B (23.0) & $F(10.7)$ & B (34.2) & C (14.9) & D (14.2) \\
\hline & 2014 & B (20.1) & D (19.5) & $F(14.2)$ & B (34.1) & $\mathrm{D}(13.5)$ & C (11.2) \\
\hline \multirow[t]{2}{*}{ Poland } & 2007 & D (31.1) & B (16.2) & $A(9.0)$ & $B(32.1)$ & D (18.5) & A (14.7) \\
\hline & 2014 & D (31.1) & B (14.8) & $F(10.4)$ & $B(35.0)$ & D (16.6) & C (13.8) \\
\hline
\end{tabular}

Symbols

\begin{tabular}{lll} 
A Agriculture & E Transport and communication & I Public administration \\
B Manufacturing & F Accommodation and food & J Education \\
C Construction & G Financial activities & K Health and social work \\
D Wholesale and retail & H Real estate, business & \\
\hline
\end{tabular}

Note: For each country, the table shows the shares of youth employment in the first three main sectors.

Source: EU-LFS; authors' analysis.

respectively. This left young men particularly exposed to the subsequent crash, and by 2014 the percentages employed in construction had fallen to under 7\% in both cases. In the other countries, excluding the Netherlands, construction remains an important source of employment for young men, accounting for at least 1 in 10 jobs. 
The changes in the distribution of youth across sectors could simply reflect overall shifts in the employment structure. In the following section, we consider whether sectors have also changed in their propensity to employ young people.

\subsection{DID EMPLOYERS HAVE A WEAKER PROPENSITY TO EMPLOY YOUNG PEOPLE DURING THE GREAT RECESSION?}

In Section 2.5, we showed that the youth share of total employment declined during the period 2007-2014 in all observed countries except Denmark and Sweden. Here, we deepen this analysis and investigate whether and to what extent employers' preferences for youth labor vary across sectors. Table 2.3 shows the share of youth within each sector. This allows us to see the concentration of youth within particular sectors-and their under-representation in others-and how these vary over time.

The highest youth share is found in the accommodation and food sector, which is particularly high at $46 \%$ in Denmark and the Netherlands. The youth share in this sector is much lower in the subprotective countries, although young people are still over-represented. Over time, however, the reliance on youth in this sector decreased in the majority of countries.

Wholesale and retail is also a youth-intensive sector: In 2007, young people accounted for more than one-fourth of those employed in this sector in Denmark, the Netherlands, Ireland, and the United Kingdom, but they accounted for less than $10 \%$ in Italy and Hungary. Over time, the youth share of employment in wholesale and retail decreased in almost all countries, and particularly in Ireland and Spain, again suggesting that youth are particularly exposed to a hiring freeze or labor shedding in this sector in some countries. Ireland and Spain also experienced the largest decline in the youth share in construction (17 pp and $10 \mathrm{pp}$, respectively). Notable decreases of between $3.5 \mathrm{pp}$ and $5 \mathrm{pp}$ are also present in France, Italy, the United Kingdom, and the Netherlands.

Beyond these marked changes, and with the exception of Denmark and Sweden, the decline in the youth share was observed in all sectors, reflecting young people's declining employment share across the economy as a whole. This evidence substantiates the argument made by Blanchflower and Freeman (2000) that there is a long-term tendency of employers to lower their propensity to employ young people. The negative impact on young people has been exacerbated during the crisis by a lower propensity of employers to hire young people and the dissolution of temporary contracts, by and large held by young people (Boeri and Jimeno 2015). We examine these trends more formally using a shift-share analysis. 
Table 2.3 Youth employment (ages 16-24 years) as a share of total employment (ages 16-64 years) by sector in 11 EU countries: 2007, 2010, and 2014 (\%)

\begin{tabular}{|c|c|c|c|c|c|c|c|c|c|c|c|c|c|c|c|}
\hline \multirow[b]{2}{*}{ Sector } & \multicolumn{3}{|c|}{ Denmark } & \multicolumn{3}{|c|}{ Sweden } & \multicolumn{3}{|c|}{ Germany } & \multicolumn{3}{|c|}{ France } & \multicolumn{3}{|c|}{ Netherlands } \\
\hline & 2007 & 2010 & 2014 & 2007 & 2010 & 2014 & 2007 & 2010 & 2014 & 2007 & 2010 & 2014 & 2007 & 2010 & 2014 \\
\hline Agriculture & 20.0 & 17.2 & 14.8 & 13.4 & 13.2 & 12.7 & 12.1 & 10.6 & 10.2 & 9.0 & 6.3 & 6.2 & 20.2 & 17.2 & 16.5 \\
\hline Manufacturing & 11.1 & 8.4 & 8.0 & 9.0 & 7.3 & 7.3 & 12.4 & 11.7 & 10.1 & 8.7 & 8.3 & 7.3 & 10.8 & 8.5 & 7.5 \\
\hline Construction & 16.2 & 15.5 & 13.5 & 12.7 & 13.6 & 12.7 & 13.2 & 12.3 & 11.3 & 15.6 & 13.5 & 10.9 & 12.0 & 11.4 & 8.6 \\
\hline Wholesale and retail & 30.5 & 32.3 & 33.7 & 16.4 & 18.5 & 18.3 & 14.5 & 14.5 & 13.0 & 13.4 & 13.2 & 12.8 & 30.8 & 31.6 & 30.0 \\
\hline $\begin{array}{l}\text { Transport and } \\
\text { communication }\end{array}$ & 11.3 & 10.6 & 10.0 & 10.0 & 8.8 & 8.7 & 7.6 & 8.1 & 7.7 & 6.8 & 7.0 & 7.0 & 14.6 & 12.5 & 9.5 \\
\hline Accommodation and food & 43.9 & 46.5 & 45.8 & 31.3 & 34.6 & 35.4 & 21.1 & 20.7 & 18.2 & 19.9 & 20.4 & 17.0 & 45.6 & 46.7 & 44.6 \\
\hline Financial services & 6.7 & 6.3 & 6.4 & 5.8 & 6.9 & 7.8 & 8.6 & 9.8 & 8.6 & 6.0 & 6.7 & 6.5 & 7.8 & 5.7 & 4.0 \\
\hline Real estate, professional & 9.9 & 10.6 & 10.5 & 8.8 & 10.8 & 9.7 & 9.3 & 9.8 & 8.1 & 8.5 & 7.6 & 6.4 & 12.9 & 12.6 & 11.7 \\
\hline Public administration & 5.1 & 6.5 & 4.2 & 2.8 & 3.7 & 4.4 & 9.2 & 7.0 & 7.3 & 4.9 & 5.1 & 4.7 & 6.0 & 5.6 & 3.4 \\
\hline Education & 4.9 & 5.7 & 6.8 & 4.0 & 5.2 & 7.0 & 9.3 & 8.4 & 8.0 & 5.1 & 5.1 & 5.3 & 5.7 & 7.2 & 7.1 \\
\hline Health and social work & 8.9 & 9.8 & 9.3 & 7.1 & 8.4 & 9.4 & 11.7 & 11.0 & 10.8 & 6.9 & 6.4 & 5.8 & 10.0 & 11.0 & 8.8 \\
\hline Arts and other services & 16.0 & 22.0 & 22.0 & 13.5 & 16.1 & 18.6 & 10.4 & 11.3 & 9.8 & 11.4 & 12.2 & 10.4 & 17.3 & 19.7 & 12.8 \\
\hline
\end{tabular}




\begin{tabular}{|c|c|c|c|c|c|c|c|c|c|c|c|c|c|c|c|c|c|c|}
\hline \multirow[b]{2}{*}{ Sector } & \multicolumn{3}{|c|}{ Ireland } & \multicolumn{3}{|c|}{ United Kingdom } & \multicolumn{3}{|c|}{ Spain } & \multicolumn{3}{|c|}{ Italy } & \multicolumn{3}{|c|}{ Hungary } & \multicolumn{3}{|c|}{ Poland } \\
\hline & 2007 & 2010 & 2014 & 2007 & 2010 & 2014 & 2007 & 2010 & 2014 & 2007 & 2010 & 2014 & 2007 & 2010 & 2014 & 2007 & 2010 & 2014 \\
\hline Agriculture & 6.9 & 6.7 & 5.9 & 13.6 & 10.8 & 12.5 & 7.7 & 7.6 & 6.0 & 5.1 & 4.4 & 4.2 & 5.4 & 5.3 & 6.2 & 8.5 & 6.8 & 5.5 \\
\hline Manufacturing & 11.9 & 7.2 & 6.0 & 10.2 & 9.9 & 9.5 & 9.7 & 4.7 & 3.3 & 7.1 & 5.2 & 4.3 & 8.2 & 6.4 & 7.4 & 10.2 & 8.6 & 8.2 \\
\hline Construction & 21.8 & 10.2 & 4.8 & 14.9 & 11.5 & 11.1 & 12.5 & 6.5 & 2.8 & 9.5 & 7.9 & 4.8 & 7.4 & 6.6 & 7.1 & 9.1 & 10.5 & 8.4 \\
\hline Wholesale and retail & 27.4 & 21.0 & 14.9 & 26.0 & 25.3 & 22.1 & 13.7 & 9.7 & 6.2 & 8.4 & 7.7 & 6.1 & 8.3 & 7.4 & 7.6 & 15.4 & 13.5 & 10.9 \\
\hline $\begin{array}{l}\text { Transport and } \\
\text { communication }\end{array}$ & 8.2 & 4.9 & 4.7 & 9.7 & 7.8 & 7.7 & 7.5 & 5.2 & 2.9 & 4.3 & 3.9 & 2.9 & 5.8 & 4.8 & 4.3 & 7.6 & 7.4 & 6.6 \\
\hline Accommodation and food & 30.9 & 25.1 & 22.4 & 37.0 & 33.1 & 35.9 & 13.6 & 10.8 & 9.9 & 14.7 & 14.1 & 13.2 & 13.5 & 14.2 & 14.6 & 26.1 & 21.9 & 19.2 \\
\hline Financial services & 16.7 & 7.1 & 4.4 & 14.3 & 9.3 & 10.8 & 5.1 & 2.3 & 1.6 & 3.7 & 3.1 & 1.3 & 7.2 & 4.1 & 3.6 & 9.1 & 9.4 & 5.0 \\
\hline Real estate, professional & 13.1 & 6.6 & 5.9 & 9.7 & 9.9 & 9.3 & 7.7 & 4.5 & 3.1 & 5.7 & 4.7 & 3.1 & 5.4 & 3.5 & 5.1 & 9.5 & 7.4 & 6.4 \\
\hline Public administration & 5.8 & 3.7 & 1.1 & 7.5 & 6.2 & 5.5 & 4.5 & 4.1 & 1.2 & 2.6 & 1.8 & 1.2 & 5.5 & 6.6 & 6.4 & 6.5 & 6.7 & 3.2 \\
\hline Education & 6.9 & 6.5 & 3.6 & 5.5 & 6.3 & 7.9 & 6.1 & 4.5 & 3.8 & 1.1 & 1.1 & 0.5 & 2.0 & 2.1 & 2.8 & 3.4 & 3.6 & 2.5 \\
\hline Health and social work & 8.5 & 5.6 & 5.0 & 8.5 & 8.8 & 9.6 & 6.3 & 5.4 & 3.6 & 2.7 & 2.3 & 2.3 & 2.7 & 2.8 & 4.1 & 3.8 & 3.7 & 2.6 \\
\hline Arts and other services & 21.6 & 17.7 & 12.7 & 20.1 & 21.5 & 19.6 & 14.5 & 12.4 & 8.3 & 9.5 & 9.6 & 8.4 & 7.0 & 7.4 & 7.4 & 12.7 & 13.2 & 9.1 \\
\hline
\end{tabular}

Source: EU-LFS; authors' analysis. 


\section{0}

The heterogeneity in the experience of youth employment among countries could be a result of several different factors. It could be the result of an overall shrinkage in the sector in question (shift) or of a declining share of youth employed in the same sector. Using a shift-share analysis, we can decompose changes in the total share of youth employment in 2007-2010 and 2010-2014 by sector. This method enables us to measure how much of the changes in youth employment are due to changes in the size of sectors (growth or sector effect), to changes in the utilization of youth labor within sectors (share effect), and to the interaction between these two forces (interaction term) (Figure 2.3).

The first thing to note is that in all countries and in both periods, changes in youth employment are driven by the share effect, namely by the fact that during the recession young people are more likely to be dismissed (or less likely to be hired) compared to older people. For example, the great decrease in youth employment that we observe for Spain in the first phase of the recession $(-3.35)$ is almost entirely due to the share effect $(-3.31)$. This supports the argument that employers have lowered their propensity to employ young people, both by imposing a hiring freeze and through the dissolution of temporary contracts.

In some cases, we observe growth and share effects operating in opposite directions at the same time. For example, in the Netherlands in the second period, the growth effect increases youth employment $(+0.35)$, but the share effect

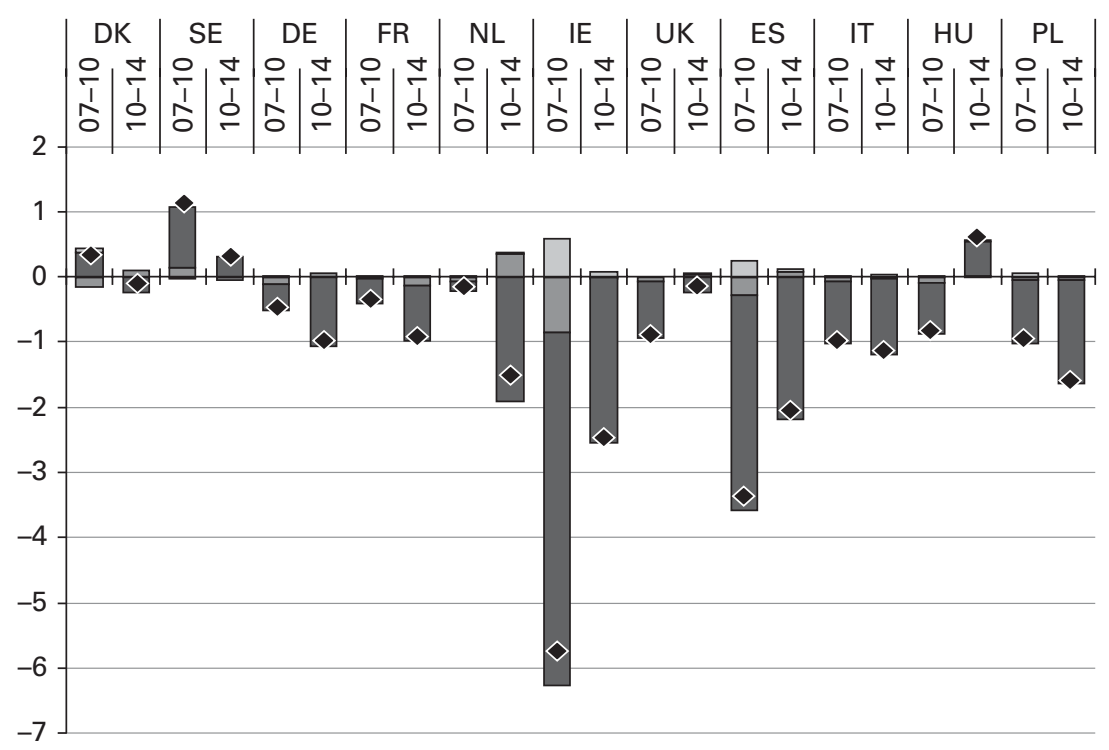

$\begin{array}{ll}- \text { Observed change } & \square \text { Share effect } \\ \square \text { Interaction term } & \square \text { Growth effect }\end{array}$

Figure 2.3 Decomposition of changes in youth employment as a share of total employment in 11 EU countries, 2007-2010 and 2010-2014 (percentage points).

Source: EU-LFS; authors' analysis. 
decreases it (-1.91). We could interpret this as being the result, on the one hand, of the expansion of some sectors that traditionally give employment to youth and, on the other hand, to a decline over time in the use of youth within these sectors. This is what has happened for the wholesale and retail sector in the Netherlands.

Although differences between countries exist in the contribution of each sector to the total share effect, the overall changes have been mainly driven by construction, manufacturing, and wholesale and retail (results not shown but available upon request). Shifts in manufacturing played a particularly important role in reducing youth employment in the first phase of the recession; this was attributable to sector shrinkage, but also to a reduction in the use of youth labor. Countries especially affected by shifts in manufacturing were Ireland and the subprotective and post-socialist countries. Construction has also been a major driver of youth unemployment especially in Spain and Ireland (where both growth and share effects contributed to falling employment rates). The wholesale and retail sector played a major role in growing youth unemployment in the liberal countries, Spain, and Poland, where the reduced use of youth within this sector contributed to the overall decline in youth employment.

Beyond this general picture, it is worth investigating which young workers have been most affected by the recession. As a first step in this direction, we look at whether changes in youth employment have been driven mainly by shifts in male or in female employment. We do so by carrying out a shift-share analysis and decomposing the changes in youth employment by gender (Figure 2.4). ${ }^{8}$ Here, we only report the share component because it has emerged as the factor that drives overall youth employment and because it addresses the issue of whether employers have lowered their propensity to employ youth. Because these results are derived from a further decomposition of the effects presented in Figure 2.3 (and in Table A2.4), the overall changes as well as the total share effect are identical.

When youth employment changes are disaggregated by gender, a clear and unique pattern does not emerge. On the one hand, changes in overall employment were driven in the universalistic and employment-centered countries by changes in female employment. This holds in the case of both employment increases (Denmark and Sweden) and decreases. On the other hand, in the subprotective and post-socialist countries, the overall changes were driven by changes in male employment. These different patterns are not surprising. Indeed, compared with employment-centered and especially with universalistic countries, countries belonging to the subprotective and post-socialist groups are characterized by considerably lower female labor market participation, implying a lower capacity of women's employment to drive changes in overall employment. It is also worth noting that whenever we observe increases in the share of youth employment, these are driven by an increased share of female employment.

A further step in studying how the recession has hit youth employment is to focus on which types of job creation and destruction have benefited or disadvantaged the youth population. We do this in Section 2.8, employing a shift-share 


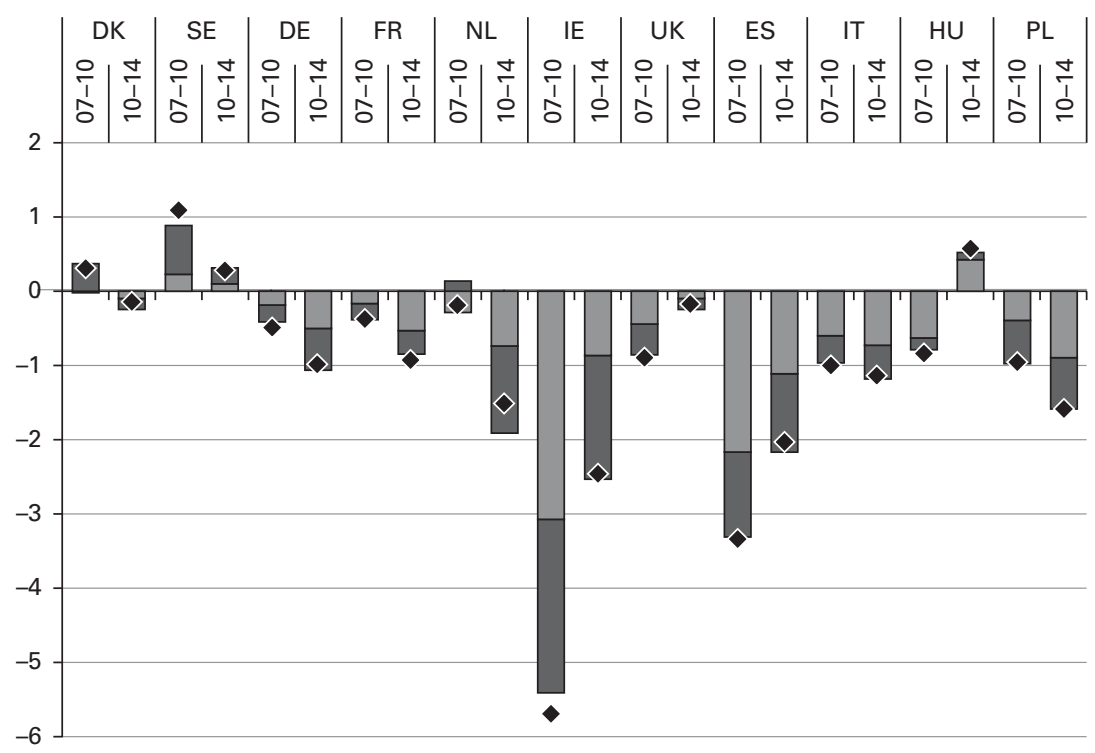

Observed change $\square$ Female $\square$ Male

Figure 2.4 Decomposition of changes in youth employment as a share of total employment in 11 EU countries, 2007-2010 and 2010-2014; share effect by gender (percentage points).

Source: EU-LFS; authors' analysis.

analysis to decompose changes in youth employment by whether employment is full- or part-time and on a permanent or temporary contract.

\subsection{HAS THE QUALITY OF YOUTH EMPLOYMENT DETERIORATED?}

In addition to the fall in employment, the situation of young people may also have worsened because of a reduction in the quality of their jobs. Were youth displaced because they were employed in jobs characterized by less secure employment contracts? Or did the youth share of temporary and part-time jobs increase because young people were increasingly hired via less desirable forms of employment contract (Blanchflower and Freeman 2000)?

First, we decompose share effects by working arrangement, distinguishing between full-time and part-time employment (Figure 2.5). Focusing on the share effects, which we have shown to drive a reduction of youth employment, we see that it is the component related to full-time employment that drives the youth employment decline; that is, the driving force is the fall in the proportion of full-time jobs that are available to young people. In some cases, the use of parttime employment among youth increased across sectors. This is the case of the 


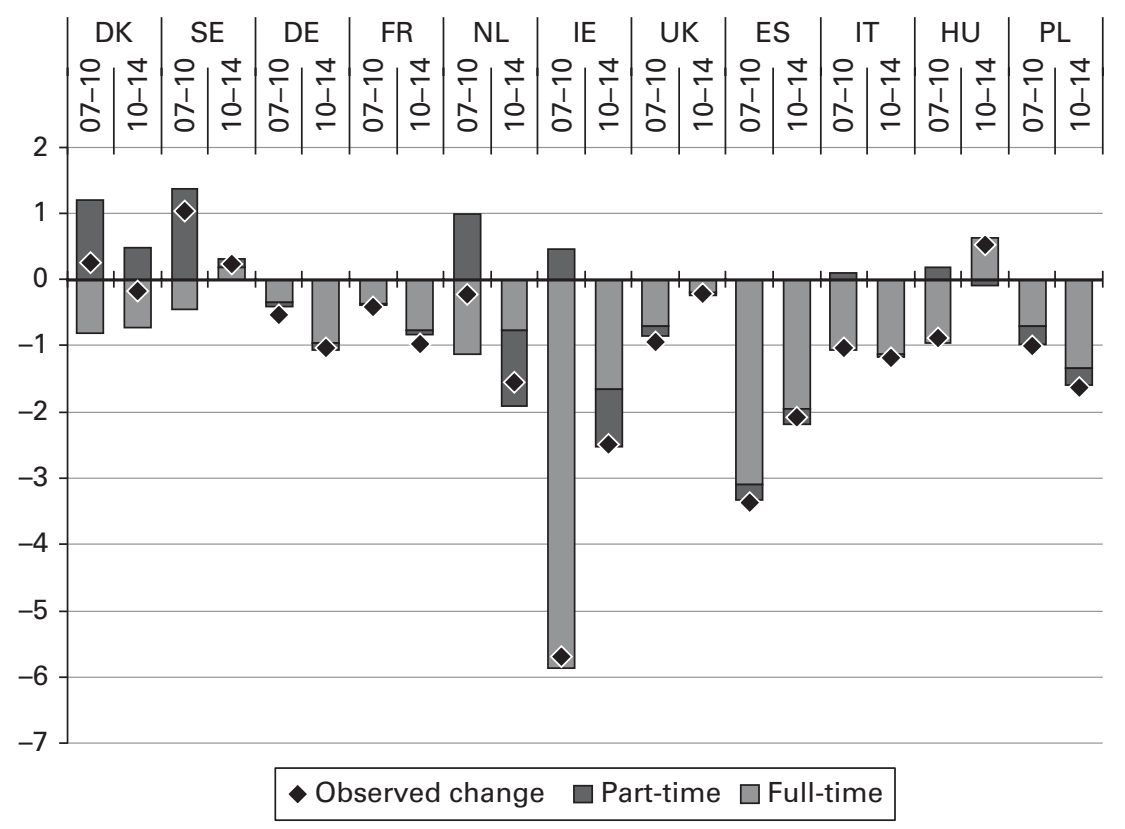

Figure 2.5 Decomposition of changes in youth employment as a share of total employment in 11 EU countries, 2007-2010 and 2010-2014; share effect by working arrangement (percentage points).

Source: EU-LFS; authors' analysis.

universalistic countries in both phases of the recession. Overall, the larger losses in full-time employment have resulted in the decline in youth employment. An emblematic example is the Netherlands during the first phase of the recession, where the decrease in youth employment resulted from two opposite forces: the increase in part-timers $(+0.98)$ and the decrease in full-timers $(-1.13)$-that is, the growth in part-time jobs did not compensate for the fall in full-time work.

Whenever we observe an overall increase in youth employment, this is often attributable to an increase in young people working part-time rather than any increase in full-time jobs, which overall have decreased. The universalistic countries in the first period are an example of this dynamic, which has been driven by the wholesale and retail sector.

Overall, we have shown that job destruction for young people mainly occurred in full-time employment; there was some decrease in part-time jobs, and in some cases, it led to an increase in youth unemployment. Young people were more at risk of remaining jobless because of an employer hiring freeze; where they were able to find work, this was more likely to be in economically less desirable jobs. The use of full-time employment declined in all sectors virtually everywhere in both phases of the recession. In the few cases in which full-time work has increased, the growth has been negligible. The generalized decline in 


\section{COMPARING PROBLEMATIC YOUTH TRANSITIONS TO WORK}

youth employment is mainly attributable to the declining full-time component; changes in the wholesale and retail, construction, and manufacturing sectors have been driving the trend, with the collapse of full-time job opportunities for young people.

The next step is to investigate another characteristic of the employment relationship, namely the type of contract. The analysis presented in Figure 2.6 reports slightly different results than those shown so far; this is because we exclude the self-employed, as discussed in Section 2.3. Focusing on employees only produces some negligible differences in the size of the changes, but the results follow the same patterns observed previously: decreases in the share of youth employment in all countries and periods, with the exception of Sweden in both periods, Denmark in the first period, and Hungary in the second period.

The share effects of the type of contract used to employ young people largely mirror those presented for full-time and part-time employment. Again, the outflow of youth from the labor market mainly derives from the loss of better jobs. Changes in the share of youth in employment are driven by declines in the share of youth in permanent employment. However, in the few cases in which we observe the youth share increasing, this comes from increases in both permanent

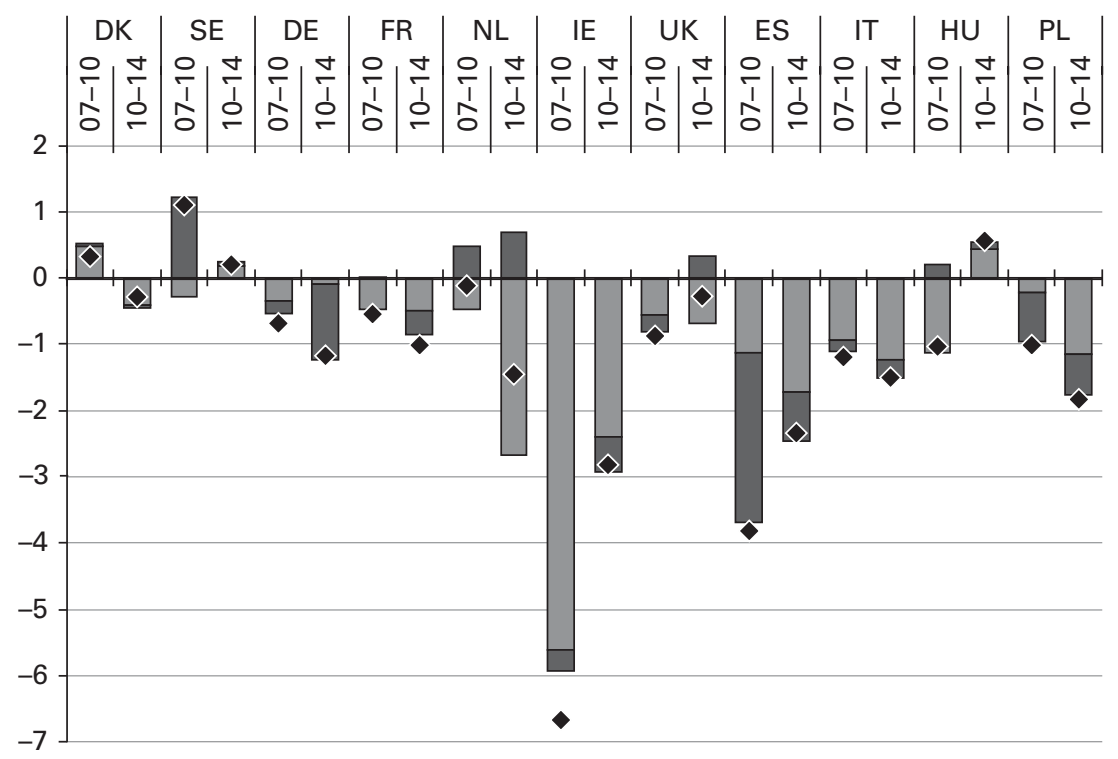

- Observed change $\square$ Temporary $\square$ Permanent

Figure 2.6 Decomposition of changes in youth employment as a share of total employment in 11 EU countries, 2007-2010 and 2010-2014; share effect by employment relationship (percentage points).

Source: EU-LFS; authors' analysis. 
and temporary youth employment, with the creation of permanent jobs driving the changes.

Great heterogeneity is also visible between countries. Of course, this is due both to the impact of the recession on total employment and to the overall use of temporary employment. For example, we observe the highest decrease $(-2.56)$ in temporary employment in Spain in the first phase of the recession, as predicted by Boeri and Jimeno (2015). This is not very surprising because Spain, among the 11 countries selected, is probably the country where the impact of the recession was greatest, and it is also the country where temporary forms of employment are more widespread.

As regards variations in growth and share effects for permanent and temporary employment across sectors, the results reflect the patterns presented in Section 2.7. Manufacturing, construction, and wholesale and retail are the sectors that have driven the decline in permanent employment for youth during the recession. This has occurred both via the shrinkage of sectors and via the declining utilization of youth within sectors.

There are a couple of caveats that should be underlined. First, in interpreting the sizes of the decomposed changes, we have to keep in mind that these changes also reflect the sizes of the groups. For example, if we observe the largest contribution of part-time employment in the Netherlands, it is probably because the Netherlands is the country where part-time employment is more widespread. The same holds for temporary employment in Spain.

Second, we have to consider that changes in the share of youth are also a product of the inflow/outflow of those aged 25 years or older into and out of employment. For example, Boeri and Jimeno $(2015,3)$ observed that a characteristic of this specific recession is that the employment rates of older people increased in most countries as pension reforms progressively increased retirement age. This, also, is a factor that contributes to accounting for the heterogeneous experience of youth unemployment across countries. Therefore, at least in principle, we might observe changes in the share of youth employment even in cases in which youth employment does not change but older people's employment does. In this sense, these analyses furnish a picture of youth employment from a different perspective-looking at the composition of employment-and complement the pictures provided by the study of the unemployment and labor force participation rates.

\subsection{CONCLUSIONS}

We set out to understand which sectors of the economy are more likely to employ young people and how this changed between 2007 and 2014. Drawing on research from the 1980s, the study illustrated the persistently uneven distribution of youth employment across sectors, regardless of cross-national differences 
in youth transition regimes. Even as the relative importance of different sectors has changed within these economies with the growth of service employment, job opportunities for youth are dominated by particular sectors. These differences have persisted and become more entrenched since the Great Recession. Young people (aged 16-24 years) have historically been more likely to find work in low-wage, low-skilled jobs where there is less competition from older workers. Despite growth in youth-friendly sectors, demographic trends showing a contraction in younger cohorts of workers, and increasing levels of youth participation in education, youth employment continues to fall, and it was falling even prior to the Great Recession. Boeri and Jimeno (2015) argue that the collapse of the youth labor market is attributable not only to a hiring freeze by employers but also to the heavy destruction of jobs held by young people through the dissolution of temporary contracts in response to the sharp deterioration in the economy and despite incentive structures shaped by policy. Blanchflower and Freeman (2000) suggested that the quality of employment and earnings for young people in these sectors has deteriorated in nearly all OECD countries because of the worsening conditions of low-paid and less skilled jobs. To test these arguments, we conducted a shift-share analysis for the period from 2007 to 2014 to examine whether these predicted trends explained overall European patterns in youth employment, and how they were affected by gender and employment status.

The share of youth employment (ages 16-24 years) relative to the total population (ages 16-64 years) has fallen over the period considered (2007-2014). This is demonstrated in our findings from a shift-share analysis. Part of this fall is attributable to the impact of the recession on reducing the overall levels of employment in some sectors-for example, construction and manufacturing. But this is only part of the explanation. It was not only that the size of the sector shrank but also that the share of employed youth fell even in sectors that were more resilient. Second, the quality of jobs for youth has deteriorated, as predicted by Blanchflower and Freeman (2000). We have seen that better quality employment declined in favor of part-time and temporary jobs during this relatively short period from 2007 to 2014.

These findings clearly contribute to improving a relatively neglected understanding of cross-national sectorial differences as to where young people find work. By drawing on earlier studies, we illustrated the persistence of this sectorial variability, despite cross-country differences. One of the clearest findings from this research is the need first to understand that youth job opportunities are very specific to sectors and that this applies regardless of country. Second, the engagement of employers is key to improving youth opportunities for work (Lewis and Ryan 2008; Simms et al., 2017). Our research evidence indicates that employers have lowered their propensity to employ youth (combining a hiring freeze with the dissolution of temporary contracts), possibly for some of the reasons outlined by Marsden and Ryan (1986) with regard to wages, productivity, 
and training costs. But closer attention needs to be given to understanding how wage rates, labor market policies, and the costs of training make employers less disposed to recruiting young people. Hadjivassiliou et al. (this volume) illustrate how countries perform better where employers are closely engaged in STW transition regimes and VET systems. Here, employers see an incentive to participate. In more fragmented regimes where there is greater inertia in the ability to involve employers through different policy channels, the outcomes for youth have been devastating, especially in subprotective countries (see Petmesidou and González Menéndez, this volume). One of the key challenges in terms of policy learning and transfer requires mobilizing employers and professional bodies within multiagency forms of governance to deliver effective programs to overcome some of the deleterious consequences for youth that have become evident in the past decade.

\section{NOTES}

1 This is similar to the youth-share statistic we report later.

2 The aggregate measures do not take into account the size of the countries (or sample size); rather, each country has a weight of one.

3 Since 2008, the applied version of NACE is "Rev. 2" (Revision 2). In the change from Rev. 1.1 to Rev. 2, some activities were disaggregated, whereas others were collapsed. In order to maximize the comparability of our data over time, we built a new classification based on the two versions (see Table A2.1 in the Appendix). The main changes involved in the shift to NACE Rev. 2 are related to the creation of a new Section J, "Information and communication," which includes activities that in Rev. 1.1 were spread across different categories. Although it was not possible to entirely eliminate potential bias, we reduced its effects by collapsing the new category with the old category I, "Transport, storage and communications." Finally, because of their small sizes, we excluded the categories "Activities of households as employers" and "Activities of extraterritorial organisations and bodies."

4 See Smith, Fagan, and Rubery (1998) for a comparable approach used to examine the use of part-time employment in Europe.

5 Significant variations between countries are also present in this respect. On the one hand, we observe in our sample for the post-socialist countries and Ireland a marked decline in the share of youth among the total population aged 16-64 years-of between 4 pp and 6 pp between 2007 and 2014. On the other hand, the share of youth increased in the universalistic countries. At the same time, Ireland is also the country in which the share of youth in employment declined the most, whereas Denmark and Sweden are the only countries in which youth in work increased.

6 The complementary figures for the whole working population are shown in Table A2.3 in the Appendix. 
7 Results of the shift-share analysis presented in Figure 2.3 are also reported in Table A2.4 in the Appendix.

8 Results are also reported in Table A2.5 in the Appendix. The same table also reports the shift-share results decomposed by working arrangement and employment relationship that will be discussed later.

\section{REFERENCES}

Bettio, Francesca, and Alina Verashchagina. 2014. "Women and Men in the 'Great European Recession.' In Women and Austerity: The Economic Crisis and the Future for Gender Equality, edited by Maria Karamessini and Jill Rubery, 57-81. Abingdon, UK: Routledge.

Blanchflower, David G., and Richard B. Freeman. 2000. “The Declining Economic Status of Young Workers in OECD Countries." In Youth Employment and Joblessness in Advanced Countries, edited by David G. Blanchflower and Richard B. Freeman, 19-56. Chicago: University of Chicago Press.

Boeri, Tito, and Juan Francisco Jimeno. 2015. "The Unbearable Divergence of Unemployment in Europe." CEP Discussion Paper 1384. London: Centre for Economic Performance, London School of Economics.

Buchmann, Marlis C., and Irene Kriesi. 2011. "Transition to Adulthood in Europe.” Annual Review of Sociology 37: 481-503.

Eichhorst, Werner, Tito Boeri, An De Coen, Vincenzo Galasso, Michael Kendzia, and Nadia Steiber. 2014. "How to Combine the Entry of Young People in the Labour Market with the Retention of Older Workers?" IZA Journal of European Labor Studies 3 (19): 1-23.

Eurostat. 2008. Statistical Classification of Economic Activities in the European Community. NACE Rev. 2. Luxembourg: Office for Official Publications of the European Communities.

Hall, Peter A., and David Soskice. 2001. Varieties of Capitalism: The Institutional Foundations of Comparative Advantage. Oxford: Oxford University Press.

Kelly, Elish, Gillian Kingston, Helen Russell, and Frances McGinnity. 2014. “The Equality Impact of the Unemployment Crisis." Journal of the Statistical and Social Inquiry Society of Ireland 44: 71-85.

Kohlrausch, Bettina. 2012. Youth Unemployment in Germany: Skill Biased Patterns of Labour Market Integration. Berlin: Friedrich-Ebert-Stiftung.

Lewis, Paul, and Paul Ryan. 2008. "A Hard Sell? The Prospects for Apprenticeship in British Retailing." Human Resource Management Journal 18 (1): 3-19.

Marsden, David, and Paul Ryan. 1986. "Where Do Young Workers Work? Youth Employment by Industry in Various European Economies." British Journal of Industrial Relations 24 (1): 83-102. 
O’Higgins, Niall. 2012. “This Time It's Different? Youth Labour Markets During 'the Great Recession.” IZA Discussion Paper 6434. Bonn: Institute for the Study of Labor.

O’Reilly, Jacqueline. 2006. "Framing Comparisons: Gendering Perspectives on Cross-National Comparisons of Welfare and Work." Work, Employment and Society 20 (4): 731-50.

O’Reilly, Jacqueline, Werner Eichhorst, András Gábos, Kari Hadjivassiliou, David Lain, Janine Leschke, Seamus McGuinness, et al. 2015. "Five Characteristics of Youth Unemployment in Europe: Flexibility, Education, Migration, Family Legacies, and EU Policy." SAGEOpen 5(1): 1-19. doi:10.1177/2158244015574962.

Organization for Economic Co-operation and Development. 2013. Education at a Glance 2013: OECD Indicators. Paris: Organization for Economic Cooperation and Development. http://www.oecd.org/education/eag2013.htm

Pohl, Axel, and Andreas Walther. 2007. "Activating the DisadvantagedVariations in Addressing Youth Transitions Across Europe." International Journal of Lifelong Education 26 (5): 533-53.

Rubery, Jill, and Anthony Rafferty. 2013. "Women and Recession Revisited." Work, Employment and Society 27 (3): 414-32.

Russell, Helen, and Philip J. O'Connell. 2001. “Getting a Job in Europe: The Transition from Unemployment to Work Among Young People in Nine European Countries." Work, Employment and Society 15 (1): 1-24.

Simms, Melanie, Sophie Gamwell, and Benjamin Hopkins. 2017. "Understanding Employer Engagement in Youth Labour Market Policy in the UK." Human Resource Management Journal. Special Issue (November): 548-64.

Smith, Mark, Colette Fagan, and Jill Rubery. 1998. "Where and Why Is PartTime Work Growing in Europe?" In Part-Time Prospects: International Comparisons of Part-Time Work in Europe, North America and the Pacific Rim, edited by Jacqueline O'Reilly and Colette Fagan, 35-56. London: Routledge.

Wallace, Claire, and René Bendit. 2009. "Youth Policies in Europe: Towards a Classification of Different Tendencies in Youth Policies in the European Union.” Perspectives on European Politics and Society 10 (3): 441-58. doi:10.1080/15705850903105868. 


\section{APPENDIX}

Table A2.1 Classification of sectors based on NACE Rev. 1.1 and NACE Rev. 2

\begin{tabular}{|c|c|c|c|c|}
\hline & $\begin{array}{l}\text { NACE Rev. } 1.1 \\
\text { (up to 2007) }\end{array}$ & & $\begin{array}{l}\text { NACE Rev. } 2 \\
\text { (from } 2008 \text { onward) }\end{array}$ & Sector \\
\hline A & $\begin{array}{l}\text { Agriculture, hunting and } \\
\text { forestry }\end{array}$ & A & $\begin{array}{l}\text { Agriculture, forestry and } \\
\text { fishing }\end{array}$ & Agriculture \\
\hline B & Fishing & & & \\
\hline C & Mining and quarrying & B & Mining and quarrying & Manufacturing \\
\hline D & Manufacturing & C & Manufacturing & \\
\hline \multirow[t]{2}{*}{$E$} & $\begin{array}{l}\text { Electricity, gas and water } \\
\text { supply }\end{array}$ & D & $\begin{array}{l}\text { Electricity, gas, steam and } \\
\text { air conditioning supply }\end{array}$ & \\
\hline & & $\mathrm{E}$ & $\begin{array}{l}\text { Water supply, sewerage, } \\
\text { waste management and } \\
\text { remediation activities }\end{array}$ & \\
\hline $\mathbf{F}$ & Construction & $\mathbf{F}$ & Construction & Construction \\
\hline G & $\begin{array}{l}\text { Wholesale and retail } \\
\text { trade: repair of motor } \\
\text { vehicles, motorcycles } \\
\text { and personal and } \\
\text { household goods }\end{array}$ & G & $\begin{array}{l}\text { Wholesale and retail } \\
\text { trade: repair of motor } \\
\text { vehicles and motorcycles }\end{array}$ & Wholesale and retail \\
\hline $\mathrm{H}$ & Hotels and restaurants & 1 & $\begin{array}{l}\text { Accommodation and food } \\
\text { service activities }\end{array}$ & $\begin{array}{l}\text { Accommodation and } \\
\text { food }\end{array}$ \\
\hline \multirow[t]{2}{*}{1} & $\begin{array}{l}\text { Transport, storage and } \\
\text { communications }\end{array}$ & $\mathrm{H}$ & Transportation and storage & $\begin{array}{l}\text { Transport and } \\
\text { communication }\end{array}$ \\
\hline & & J & $\begin{array}{l}\text { Information and } \\
\text { communication }\end{array}$ & \\
\hline$J$ & Financial intermediation & K & $\begin{array}{l}\text { Financial and insurance } \\
\text { activities }\end{array}$ & Financial activities \\
\hline \multirow[t]{3}{*}{ K } & $\begin{array}{l}\text { Real estate, renting and } \\
\text { business activities }\end{array}$ & $\mathbf{L}$ & Real estate activities & $\begin{array}{l}\text { Real estate, business; } \\
\text { Professional and }\end{array}$ \\
\hline & & M & $\begin{array}{l}\text { Professional, scientific and } \\
\text { technical activities }\end{array}$ & technical activities \\
\hline & & $\mathbf{N}$ & $\begin{array}{l}\text { Administrative and support } \\
\text { service activities }\end{array}$ & \\
\hline $\mathbf{L}$ & $\begin{array}{l}\text { Public administration } \\
\text { and defence; } \\
\text { compulsory social } \\
\text { security }\end{array}$ & O & $\begin{array}{l}\text { Public administration and } \\
\text { defence; compulsory } \\
\text { social security }\end{array}$ & Public administration \\
\hline
\end{tabular}


Table A2.1 Continued

\begin{tabular}{|c|c|c|c|c|}
\hline & $\begin{array}{l}\text { NACE Rev. } 1.1 \\
\text { (up to 2007) }\end{array}$ & & $\begin{array}{l}\text { NACE Rev. } 2 \\
\text { (from } 2008 \text { onward) }\end{array}$ & Sector \\
\hline M & Education & $\mathbf{P}$ & Education & Education \\
\hline $\mathbf{N}$ & Health and social work & Q & $\begin{array}{l}\text { Human health and social } \\
\text { work activities }\end{array}$ & $\begin{array}{l}\text { Health and social } \\
\text { work }\end{array}$ \\
\hline \multirow[t]{2}{*}{0} & $\begin{array}{l}\text { Other community, social } \\
\text { and personal services } \\
\text { activities }\end{array}$ & $\mathbf{R}$ & $\begin{array}{l}\text { Arts, entertainment and } \\
\text { recreation }\end{array}$ & $\begin{array}{l}\text { Arts and other } \\
\text { services }\end{array}$ \\
\hline & & S & Other service activities & \\
\hline $\mathbf{P}$ & $\begin{array}{l}\text { Activities of private } \\
\text { households as } \\
\text { employers and } \\
\text { undifferentiated } \\
\text { production activities } \\
\text { of private households }\end{array}$ & $T$ & $\begin{array}{l}\text { Activities of households } \\
\text { as employers; } \\
\text { undifferentiated goods- } \\
\text { and services-producing } \\
\text { activities of households } \\
\text { for own use }\end{array}$ & $\begin{array}{l}\text { Excluded (small size } \\
\text { sectors) }\end{array}$ \\
\hline Q & $\begin{array}{l}\text { Extraterritorial } \\
\text { organizations and } \\
\text { bodies }\end{array}$ & U & $\begin{array}{l}\text { Activities of extraterritorial } \\
\text { organizations and bodies }\end{array}$ & \\
\hline
\end{tabular}


Table A2.2a Distribution of employed youth (aged 16-24 years) across sectors in 11 EU countries, 2007 and 2014 (\%), females

\begin{tabular}{|c|c|c|c|c|c|c|c|c|c|c|}
\hline \multirow[b]{2}{*}{ Sector } & \multicolumn{2}{|c|}{ Denmark } & \multicolumn{2}{|c|}{ Sweden } & \multicolumn{2}{|c|}{ Germany } & \multicolumn{2}{|c|}{ France } & \multicolumn{2}{|c|}{ Netherlands } \\
\hline & 2007 & 2014 & 2007 & 2014 & 2007 & 2014 & 2007 & 2014 & 2007 & 2014 \\
\hline Agriculture & 2.1 & 0.8 & 1.4 & 1.0 & 1.4 & 0.7 & 1.3 & 0.8 & 1.9 & 1.4 \\
\hline Manufacturing & 10.1 & 5.2 & 6.1 & 4.1 & 15.0 & 12.7 & 10.8 & 8.7 & 5.7 & 3.2 \\
\hline Construction & 1.0 & 0.9 & 1.0 & 1.2 & 1.0 & 1.6 & 1.0 & 1.4 & 0.4 & 0.3 \\
\hline Wholesale and retail & 34.0 & 34.4 & 22.8 & 21.1 & 19.4 & 18.6 & 22.1 & 23.7 & 31.3 & 37.1 \\
\hline Transport and communication & 3.8 & 3.7 & 3.9 & 4.2 & 2.3 & 4.4 & 3.2 & 4.6 & 3.1 & 2.6 \\
\hline Accommodation and food & 11.4 & 14.4 & 14.0 & 14.1 & 9.8 & 8.8 & 8.5 & 8.3 & 13.8 & 12.6 \\
\hline Financial activities & 1.2 & 1.4 & 1.3 & 1.4 & 3.2 & 3.1 & 3.4 & 3.3 & 1.9 & 0.9 \\
\hline Real estate, business & 6.9 & 6.4 & 11.5 & 11.1 & 9.7 & 10.0 & 11.0 & 10.2 & 11.0 & 11.3 \\
\hline Public administration & 1.4 & 1.3 & 1.9 & 2.1 & 6.0 & 5.0 & 5.8 & 5.5 & 1.9 & 1.4 \\
\hline Education & 3.0 & 4.6 & 6.9 & 9.3 & 5.9 & 7.6 & 6.6 & 6.0 & 3.6 & 4.7 \\
\hline Health and social work & 17.7 & 18.1 & 20.8 & 20.2 & 19.3 & 22.5 & 17.4 & 19.9 & 18.6 & 19.4 \\
\hline Arts and other services & 7.4 & 8.9 & 8.6 & 10.1 & 7.0 & 5.2 & 8.9 & 7.6 & 6.8 & 5.2 \\
\hline
\end{tabular}




\begin{tabular}{|c|c|c|c|c|c|c|c|c|c|c|c|c|}
\hline Sector & \multicolumn{2}{|c|}{ Ireland } & \multicolumn{2}{|c|}{ United Kingdom } & \multicolumn{2}{|c|}{ Spain } & \multicolumn{2}{|c|}{ Italy } & \multicolumn{2}{|c|}{ Hungary } & \multicolumn{2}{|c|}{ Poland } \\
\hline Agriculture & 0.4 & 1.0 & 0.6 & 0.3 & 2.0 & 2.6 & 1.6 & 1.5 & 1.4 & 2.2 & 9.0 & 4.9 \\
\hline Construction & 1.3 & 0.3 & 1.3 & 1.3 & 1.9 & 0.2 & 1.5 & 0.9 & 1.2 & 1.3 & 0.7 & 1.6 \\
\hline Wholesale and retail & 30.6 & 29.1 & 28.0 & 24.6 & 30.9 & 27.4 & 23.5 & 24.7 & 25.2 & 19.5 & 31.1 & 31.1 \\
\hline Financial activities & 6.4 & 2.4 & 5.4 & 3.0 & 1.8 & 1.5 & 2.6 & 1.6 & 4.4 & 1.8 & 4.2 & 3.1 \\
\hline Real estate, business & 8.4 & 7.3 & 9.3 & 8.3 & 9.7 & 8.4 & 13.5 & 10.0 & 6.9 & 6.9 & 5.9 & 8.7 \\
\hline Public administration & 1.9 & 0.7 & 4.0 & 2.5 & 1.8 & 0.7 & 1.4 & 0.7 & 5.3 & 8.8 & 6.4 & 4.3 \\
\hline Education & 4.9 & 5.4 & 5.0 & 9.5 & 5.9 & 8.5 & 2.3 & 1.3 & 4.6 & 5.9 & 4.8 & 6.1 \\
\hline Health and social work & 10.7 & 14.2 & 13.1 & 16.4 & 8.7 & 11.8 & 5.8 & 9.1 & 4.6 & 8.3 & 4.2 & 4.3 \\
\hline
\end{tabular}

Source: EU-LFS; authors' analysis. 
Table A2.2b Distribution of employed youth (aged 16-24 years) across sectors in 11 EU countries, 2007 and 2014 (\%), males

\begin{tabular}{|c|c|c|c|c|c|c|c|c|c|c|}
\hline \multirow[b]{2}{*}{ Sector } & \multicolumn{2}{|c|}{ Denmark } & \multicolumn{2}{|c|}{ Sweden } & \multicolumn{2}{|c|}{ Germany } & \multicolumn{2}{|c|}{ France } & \multicolumn{2}{|c|}{ Netherlands } \\
\hline & 2007 & 2014 & 2007 & 2014 & 2007 & 2014 & 2007 & 2014 & 2007 & 2014 \\
\hline Agriculture & 5.5 & 3.9 & 3.7 & 2.9 & 3.1 & 1.9 & 5.1 & 3.3 & 5.6 & 3.8 \\
\hline Manufacturing & 15.2 & 9.4 & 20.0 & 11.7 & 34.2 & 28.9 & 19.9 & 16.5 & 12.9 & 8.7 \\
\hline Construction & 14.4 & 10.3 & 13.9 & 14.0 & 13.1 & 12.8 & 20.8 & 16.3 & 9.2 & 6.3 \\
\hline Wholesale and retail & 29.5 & 30.3 & 18.8 & 17.8 & 14.2 & 17.6 & 18.3 & 18.8 & 27.8 & 33.4 \\
\hline Transport and communication & 6.0 & 8.6 & 8.4 & 10.4 & 5.0 & 7.3 & 5.9 & 9.9 & 8.6 & 8.3 \\
\hline Accommodation and food & 7.0 & 10.5 & 6.2 & 7.8 & 4.0 & 5.1 & 7.2 & 7.2 & 11.0 & 15.2 \\
\hline Financial activities & 1.6 & 1.2 & 1.0 & 1.6 & 2.3 & 2.4 & 1.1 & 2.4 & 1.4 & 1.2 \\
\hline Real estate, business & 6.3 & 7.6 & 14.2 & 13.9 & 7.0 & 7.2 & 9.1 & 8.2 & 11.8 & 11.8 \\
\hline Public administration & 2.6 & 1.9 & 1.3 & 2.9 & 5.9 & 5.2 & 5.0 & 5.8 & 3.4 & 2.0 \\
\hline Education & 2.3 & 4.4 & 2.6 & 4.8 & 3.9 & 3.2 & 1.5 & 4.3 & 1.6 & 2.8 \\
\hline Health and social work & 5.1 & 6.0 & 5.1 & 5.9 & 4.7 & 5.5 & 3.0 & 3.7 & 2.7 & 3.2 \\
\hline Arts and other services & 4.5 & 5.9 & 4.9 & 6.5 & 2.8 & 2.9 & 3.1 & 3.6 & 4.2 & 3.2 \\
\hline
\end{tabular}




\begin{tabular}{|c|c|c|c|c|c|c|c|c|c|c|c|c|}
\hline Sector & \multicolumn{2}{|c|}{ Ireland } & \multicolumn{2}{|c|}{ United Kingdom } & \multicolumn{2}{|c|}{ Spain } & \multicolumn{2}{|c|}{ Italy } & \multicolumn{2}{|c|}{ Hungary } & \multicolumn{2}{|c|}{ Poland } \\
\hline Agriculture & 3.7 & 6.0 & 1.9 & 2.0 & 4.5 & 8.7 & 4.0 & 4.8 & 5.3 & 6.2 & 14.7 & 11.4 \\
\hline Construction & 33.5 & 6.6 & 16.3 & 11.5 & 27.0 & 6.8 & 19.3 & 12.0 & 14.9 & 11.2 & 11.0 & 13.8 \\
\hline Wholesale and retail & 19.9 & 25.1 & 25.5 & 22.2 & 15.9 & 20.9 & 17.5 & 18.6 & 14.2 & 13.5 & 18.5 & 16.6 \\
\hline Financial activities & 3.1 & 2.9 & 3.8 & 3.7 & 0.9 & 0.7 & 1.0 & 0.4 & 0.9 & 0.9 & 0.8 & 0.7 \\
\hline Real estate, business & 7.0 & 7.6 & 7.4 & 10.0 & 7.0 & 7.3 & 7.1 & 6.9 & 5.0 & 5.7 & 6.4 & 5.0 \\
\hline Public administration & 1.7 & 0.7 & 3.8 & 2.7 & 3.7 & 3.3 & 3.3 & 2.2 & 6.0 & 9.8 & 2.5 & 2.3 \\
\hline Education & 1.0 & 2.3 & 2.4 & 3.7 & 2.2 & 4.0 & 0.5 & 0.4 & 0.9 & 1.6 & 0.9 & 0.6 \\
\hline Health and social work & 1.0 & 2.8 & 1.9 & 3.9 & 1.3 & 2.7 & 1.1 & 1.4 & 1.3 & 1.2 & 0.8 & 0.6 \\
\hline
\end{tabular}

Source: EU-LFS; authors' analysis. 
Table A2.3 Distribution of total employment (ages 16-64 years) across sectors in 11 EU countries, 2007 and 2014 (\%)

\begin{tabular}{|c|c|c|c|c|c|c|c|c|c|c|c|c|c|c|c|}
\hline \multirow[b]{2}{*}{ Sector } & \multicolumn{3}{|c|}{ Denmark } & \multicolumn{3}{|c|}{ Sweden } & \multicolumn{3}{|c|}{ Germany } & \multicolumn{3}{|c|}{ France } & \multicolumn{3}{|c|}{ Netherlands } \\
\hline & 2007 & 2010 & 2014 & 2007 & 2010 & 2014 & 2007 & 2010 & 2014 & 2007 & 2010 & 2014 & 2007 & 2010 & 2014 \\
\hline Agriculture & 2.79 & 2.32 & 2.32 & 2.00 & 1.85 & 1.69 & 2.19 & 1.48 & 1.34 & 3.53 & 2.94 & 2.79 & 2.84 & 2.59 & 2.08 \\
\hline Manufacturing & 16.57 & 13.86 & 13.38 & 15.45 & 13.34 & 12.17 & 23.79 & 22.20 & 21.58 & 16.97 & 15.40 & 14.00 & 13.45 & 11.63 & 10.91 \\
\hline Construction & 7.09 & 5.88 & 6.05 & 6.39 & 6.73 & 6.69 & 6.61 & 6.78 & 6.85 & 7.10 & 7.52 & 6.88 & 6.33 & 6.11 & 5.32 \\
\hline Wholesale and retail & 14.93 & 14.70 & 13.94 & 12.28 & 12.33 & 11.89 & 13.50 & 12.90 & 14.08 & 13.80 & 13.45 & 13.09 & 14.88 & 14.49 & 16.24 \\
\hline $\begin{array}{l}\text { Transport and } \\
\text { communication }\end{array}$ & 6.29 & 8.82 & 8.96 & 6.25 & 9.30 & 9.39 & 5.65 & 8.15 & 7.83 & 6.40 & 8.42 & 8.48 & 6.31 & 9.18 & 7.84 \\
\hline Accommodation and food & 2.97 & 3.30 & 3.95 & 3.20 & 3.47 & 3.44 & 3.70 & 3.90 & 3.84 & 3.63 & 3.89 & 3.61 & 4.20 & 4.45 & 4.32 \\
\hline Financial services & 2.99 & 3.23 & 2.93 & 1.99 & 2.16 & 2.12 & 3.68 & 3.38 & 3.25 & 3.25 & 3.49 & 3.41 & 3.29 & 3.05 & 3.66 \\
\hline Real estate, professional & 9.61 & 9.34 & 9.64 & 14.57 & 13.36 & 14.36 & 10.40 & 10.75 & 10.65 & 10.92 & 9.97 & 11.31 & 13.61 & 10.96 & 13.52 \\
\hline Public administration & 5.73 & 5.89 & 5.57 & 5.74 & 5.95 & 6.43 & 7.54 & 7.49 & 7.17 & 10.03 & 10.23 & 9.54 & 6.88 & 7.34 & 6.70 \\
\hline Education & 7.81 & 8.55 & 9.54 & 10.87 & 10.93 & 11.28 & 6.03 & 6.63 & 6.64 & 6.97 & 6.99 & 7.66 & 6.94 & 7.57 & 7.25 \\
\hline Health and social work & 17.90 & 19.37 & 18.84 & 16.10 & 15.61 & 15.56 & 11.62 & 12.26 & 12.67 & 12.77 & 13.41 & 15.12 & 16.39 & 18.21 & 17.62 \\
\hline Arts and other services & 5.31 & 4.74 & 4.87 & 5.17 & 4.98 & 5.00 & 5.31 & 4.08 & 4.10 & 4.63 & 4.29 & 4.12 & 4.88 & 4.41 & 4.53 \\
\hline
\end{tabular}




\begin{tabular}{|c|c|c|c|c|c|c|c|c|c|c|c|c|c|c|c|c|c|c|}
\hline \multirow[b]{2}{*}{ Sector } & \multicolumn{3}{|c|}{ Ireland } & \multicolumn{3}{|c|}{ United Kingdom } & \multicolumn{3}{|c|}{ Spain } & \multicolumn{3}{|c|}{ Italy } & \multicolumn{3}{|c|}{ Hungary } & \multicolumn{3}{|c|}{ Poland } \\
\hline & 2007 & 2010 & 2014 & 2007 & 2010 & 2014 & 2007 & 2010 & 2014 & 2007 & 2010 & 2014 & 2007 & 2010 & 2014 & 2007 & 2010 & 2014 \\
\hline Agriculture & 4.82 & 3.93 & 4.74 & 1.26 & 1.08 & 1.17 & 4.46 & 4.21 & 4.39 & 3.86 & 3.69 & 3.58 & 4.59 & 4.52 & 4.62 & 14.06 & 12.62 & 11.26 \\
\hline Manufacturing & 14.16 & 13.31 & 12.83 & 14.18 & 11.85 & 11.65 & 16.99 & 15.13 & 14.12 & 22.26 & 20.85 & 21.14 & 24.22 & 23.49 & 24.34 & 24.13 & 22.45 & 23.30 \\
\hline Construction & 13.61 & 6.54 & 5.85 & 8.26 & 7.85 & 7.39 & 13.28 & 9.01 & 5.94 & 8.54 & 8.62 & 6.94 & 8.47 & 7.35 & 6.33 & 7.00 & 8.21 & 7.55 \\
\hline Wholesale and retail & 14.58 & 14.88 & 14.37 & 14.37 & 14.05 & 13.55 & 15.77 & 16.07 & 17.17 & 15.37 & 14.91 & 14.91 & 15.15 & 14.44 & 13.52 & 15.02 & 14.93 & 14.60 \\
\hline $\begin{array}{l}\text { Transport and } \\
\text { communication }\end{array}$ & 5.85 & 9.08 & 9.09 & 6.84 & 8.60 & 8.90 & 6.22 & 8.05 & 8.51 & 5.54 & 7.25 & 7.48 & 7.73 & 9.35 & 8.93 & 6.48 & 7.63 & 8.18 \\
\hline Accommodation and food & 6.44 & 6.86 & 7.32 & 4.50 & 5.13 & 5.40 & 7.19 & 7.44 & 8.17 & 5.05 & 5.30 & 5.92 & 4.19 & 4.11 & 4.21 & 1.94 & 2.22 & 2.13 \\
\hline Financial services & 4.42 & 5.05 & 4.85 & 4.45 & 4.10 & 3.97 & 2.53 & 2.67 & 2.91 & 2.93 & 3.00 & 2.87 & 2.19 & 2.44 & 2.32 & 2.42 & 2.32 & 2.40 \\
\hline Real estate, professional & 9.42 & 9.18 & 10.00 & 12.01 & 11.89 & 12.53 & 10.33 & 10.38 & 11.14 & 10.97 & 10.76 & 11.21 & 7.21 & 7.13 & 7.79 & 6.26 & 6.64 & 7.25 \\
\hline Public administration & 5.02 & 5.71 & 5.20 & 7.17 & 6.46 & 6.06 & 6.43 & 8.07 & 7.48 & 6.30 & 6.47 & 6.05 & 7.01 & 8.28 & 9.47 & 6.22 & 6.61 & 6.77 \\
\hline Education & 6.52 & 8.05 & 8.02 & 9.21 & 10.52 & 10.56 & 5.99 & 6.79 & 7.13 & 7.12 & 7.03 & 7.09 & 7.97 & 8.41 & 7.96 & 7.40 & 7.81 & 7.90 \\
\hline Health and social work & 10.36 & 12.80 & 13.20 & 12.04 & 13.51 & 13.43 & 6.73 & 7.83 & 8.49 & 6.96 & 7.51 & 8.42 & 6.67 & 6.74 & 6.71 & 5.74 & 5.82 & 5.85 \\
\hline Arts and other services & 4.81 & 4.59 & 4.54 & 5.70 & 4.95 & 5.39 & 4.08 & 4.34 & 4.55 & 5.10 & 4.60 & 4.39 & 4.60 & 3.74 & 3.81 & 3.34 & 2.76 & 2.80 \\
\hline
\end{tabular}

Source: EU-LFS; authors' analysis. 


\section{COMPARING PROBLEMATIC YOUTH TRANSITIONS TO WORK}

Table A2.4 Decomposition of changes in youth employment (ages 16-24 years) as a share of total employment (ages 16-64 years) in 11 EU countries: 2007-2010 and 2010-2014 (percentage points)

\begin{tabular}{|c|c|c|c|c|c|}
\hline Country & Period & $\begin{array}{l}\text { Observed } \\
\text { change }\end{array}$ & Growth effect & Share effect & $\begin{array}{l}\text { Interaction } \\
\text { term }\end{array}$ \\
\hline \multirow[t]{2}{*}{ Denmark } & $2007-10$ & 0.28 & -0.16 & 0.37 & 0.06 \\
\hline & 2010-14 & -0.15 & 0.09 & -0.23 & 0.00 \\
\hline \multirow[t]{2}{*}{ Sweden } & $2007-10$ & 1.06 & 0.15 & 0.91 & -0.01 \\
\hline & 2010-14 & 0.26 & -0.06 & 0.32 & 0.00 \\
\hline \multirow[t]{2}{*}{ Ireland } & $2007-10$ & -5.68 & -0.85 & -5.41 & 0.58 \\
\hline & 2010-14 & -2.47 & -0.01 & -2.53 & 0.07 \\
\hline \multirow{2}{*}{ United Kingdom } & $2007-10$ & -0.92 & -0.07 & -0.86 & 0.00 \\
\hline & 2010-14 & -0.19 & 0.03 & -0.24 & 0.02 \\
\hline \multirow[t]{2}{*}{ Germany } & 2007-10 & -0.51 & -0.11 & -0.41 & 0.01 \\
\hline & 2010-14 & -1.01 & 0.06 & -1.06 & 0.00 \\
\hline \multirow[t]{2}{*}{ France } & 2007-10 & -0.39 & -0.03 & -0.38 & 0.02 \\
\hline & 2010-14 & -0.95 & -0.13 & -0.85 & 0.02 \\
\hline \multirow[t]{2}{*}{ Netherlands } & 2007-10 & -0.20 & -0.07 & -0.15 & 0.02 \\
\hline & 2010-14 & -1.53 & 0.35 & -1.91 & 0.03 \\
\hline \multirow[t]{2}{*}{ Spain } & 2007-10 & -3.35 & -0.28 & -3.31 & 0.24 \\
\hline & 2010-14 & -2.06 & 0.07 & -2.18 & 0.05 \\
\hline \multirow[t]{2}{*}{ Italy } & 2007-10 & -1.01 & -0.07 & -0.96 & 0.02 \\
\hline & 2010-14 & -1.16 & -0.02 & -1.18 & 0.04 \\
\hline \multirow[t]{2}{*}{ Hungary } & 2007-10 & -0.86 & -0.09 & -0.79 & 0.01 \\
\hline & 2010-14 & 0.55 & 0.01 & 0.53 & 0.01 \\
\hline \multirow[t]{2}{*}{ Poland } & $2007-10$ & -0.98 & -0.04 & -0.98 & 0.05 \\
\hline & 2010-14 & -1.61 & -0.04 & -1.59 & 0.02 \\
\hline
\end{tabular}

Source: EU-LFS; authors' analysis. 
Table A2.5 Decomposition of changes in youth employment (ages 16-24 years) as a share of total employment (ages 16-64 years): 2007-2010 and 2010-2014; share effect by gender, working arrangement, and employment relationship

\begin{tabular}{|c|c|c|c|c|c|c|c|c|c|}
\hline \multirow[b]{2}{*}{ Country } & \multirow[b]{2}{*}{ Period } & \multirow{2}{*}{$\begin{array}{l}\text { Observed } \\
\text { change in } \\
\text { overall } \\
\text { employment }\end{array}$} & \multicolumn{2}{|c|}{ Gender } & \multicolumn{2}{|c|}{ Working arrangement } & \multirow{2}{*}{$\begin{array}{l}\text { Observed } \\
\text { change in } \\
\text { employees } \\
\text { only }\end{array}$} & \multicolumn{2}{|c|}{ Employment relationship } \\
\hline & & & Male & Female & Full-time & Part-time & & Permanent & Temporary \\
\hline \multirow[t]{2}{*}{ Denmark } & $2007-2010$ & 0.28 & -0.01 & 0.38 & -0.81 & 1.19 & 0.35 & 0.48 & 0.05 \\
\hline & 2010-2014 & -0.15 & -0.10 & -0.14 & -0.72 & 0.48 & -0.26 & -0.40 & -0.05 \\
\hline \multirow[t]{2}{*}{ Sweden } & $2007-2010$ & 1.06 & 0.24 & 0.66 & -0.45 & 1.36 & 1.13 & -0.28 & 1.21 \\
\hline & $2010-2014$ & 0.26 & 0.10 & 0.22 & 0.18 & 0.13 & 0.23 & 0.19 & 0.05 \\
\hline \multirow[t]{2}{*}{ Germany } & $2007-2010$ & -0.51 & -0.18 & -0.23 & -0.35 & -0.06 & -0.66 & -0.34 & -0.19 \\
\hline & 2010-2014 & -1.01 & -0.49 & -0.57 & -0.95 & -0.11 & -1.15 & -0.09 & -1.14 \\
\hline \multirow[t]{2}{*}{ France } & $2007-2010$ & -0.39 & -0.16 & -0.22 & -0.36 & -0.03 & -0.52 & -0.47 & 0.01 \\
\hline & 2010-2014 & -0.95 & -0.53 & -0.31 & -0.77 & -0.07 & -0.99 & -0.49 & -0.37 \\
\hline \multirow[t]{2}{*}{ Netherlands } & $2007-2010$ & -0.20 & -0.28 & 0.14 & -1.13 & 0.98 & -0.09 & -0.48 & 0.48 \\
\hline & 2010-2014 & -1.53 & -0.73 & -1.18 & -0.77 & -1.14 & -1.43 & -2.67 & 0.70 \\
\hline \multirow[t]{2}{*}{ Ireland } & $2007-2010$ & -5.68 & -3.07 & -2.35 & -5.86 & 0.45 & -6.66 & -5.61 & -0.31 \\
\hline & 2010-2014 & -2.47 & -0.86 & -1.67 & -1.66 & -0.87 & -2.80 & -2.39 & -0.54 \\
\hline \multirow[t]{2}{*}{ United Kingdom } & $2007-2010$ & -0.92 & -0.43 & -0.42 & -0.70 & -0.15 & -0.85 & -0.55 & -0.27 \\
\hline & 2010-2014 & -0.19 & -0.09 & -0.15 & -0.19 & -0.05 & -0.25 & -0.69 & 0.33 \\
\hline \multirow[t]{2}{*}{ Spain } & $2007-2010$ & -3.35 & -2.17 & -1.14 & -3.10 & -0.22 & -3.80 & -1.13 & -2.56 \\
\hline & 2010-2014 & -2.06 & -1.11 & -1.06 & -1.95 & -0.23 & -2.32 & -1.72 & $\begin{array}{l}-0.74 \\
\text { (continued) }\end{array}$ \\
\hline
\end{tabular}


Table A2.5 Continued

\begin{tabular}{|c|c|c|c|c|c|c|c|c|c|}
\hline \multirow[b]{2}{*}{ Country } & \multirow[b]{2}{*}{ Period } & \multirow{2}{*}{$\begin{array}{l}\text { Observed } \\
\text { change in } \\
\text { overall } \\
\text { employment }\end{array}$} & \multicolumn{2}{|c|}{ Gender } & \multicolumn{2}{|c|}{ Working arrangement } & \multirow{2}{*}{$\begin{array}{l}\text { Observed } \\
\text { change in } \\
\text { employees } \\
\text { only }\end{array}$} & \multicolumn{2}{|c|}{ Employment relationship } \\
\hline & & & Male & Female & Full-time & Part-time & & Permanent & Temporary \\
\hline \multirow[t]{2}{*}{ Italy } & $2007-2010$ & -1.01 & -0.60 & -0.36 & -1.06 & 0.10 & -1.17 & -0.94 & -0.17 \\
\hline & 2010-2014 & -1.16 & -0.72 & -0.46 & -1.13 & -0.05 & -1.48 & -1.23 & -0.28 \\
\hline \multirow[t]{2}{*}{ Hungary } & $2007-2010$ & -0.86 & -0.63 & -0.15 & -0.97 & 0.18 & -1.01 & -1.12 & 0.20 \\
\hline & 2010-2014 & 0.55 & 0.43 & 0.09 & 0.62 & -0.10 & 0.59 & 0.44 & 0.11 \\
\hline \multirow[t]{2}{*}{ Poland } & $2007-2010$ & -0.98 & -0.40 & -0.58 & -0.70 & -0.28 & -0.99 & -0.22 & -0.73 \\
\hline & 2010-2014 & -1.61 & -0.89 & -0.70 & -1.35 & -0.25 & -1.81 & -1.16 & -0.61 \\
\hline
\end{tabular}

Source: EU-LFS; authors' analysis. 